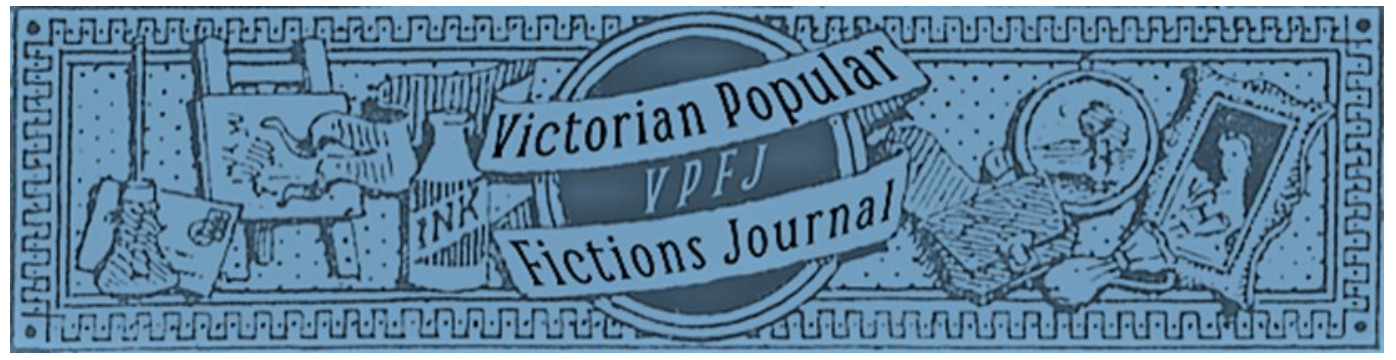

\title{
"A strange enough region wherein to wander and muse": Mapping Clerkenwell in Victorian Popular Fictions
}

\author{
Minna Vuohelainen
}

\begin{abstract}
Drawing on the work of Bertrand Westphal, this essay attempts to perform a geocritical reading of the London district of Clerkenwell. After discussing the spatial turn in the Humanities and introducing a range of spatial critical approaches, the essay "maps" literary Clerkenwell from the perspectives of genre hybridity and intertextuality, spatially articulate cartography, multifocal and historically aware public perception and potentially transgressive connection to outside areas. Clerkenwell is seen to have stimulated a range of genre fiction, including Newgate, realist, penny and slum fiction, and social exploration journalism. In much of this writing, the district was defined by its negative associations with crime, poverty, incarceration and slaughter. Such negative imageability, the essay suggests, was self-perpetuating, since authors would be influenced by their reading to create literary worlds repeating existing tropes; these literary representations, in turn, influenced readers' perceptions of the area. Intertextual, multi-layered and polysensorial geocritical readings, the essay concludes, can produce powerful and nuanced pictures of literary places but also face a formidable challenge in defining an adequate geocentric corpus.
\end{abstract}

\section{Key words}

spatial turn; spatial literary studies; cartography; mapping; geocriticism; imageability; genre; Clerkenwell; Victorian popular fiction.

Date of Acceptance: 23 December 2019

Date of Publication: 31 December 2019

Double Blind Peer Reviewed

\section{Recommended Citation:}

Vuohelainen, Minna. 2019. "Introduction: Mapping Victorian Popular Fictions: 'A strange enough region wherein to wander and muse': Mapping Literary Clerkenwell." Victorian Popular Fictions, 1.2: 3-32. ISSN: 2632-4253 (online) DOI: https://doi.org/10.46911/QPTD4864

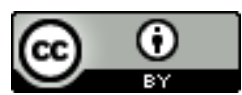

This work is licensed under a Creative Commons Attribution 4.0 International License. 


\title{
"A strange enough region wherein to wander and muse": Mapping Clerkenwell in Victorian Popular Fictions
}

\author{
Minna Vuohelainen
}

\section{Introduction: Mapping Victorian Popular Fictions}

In Charles Dickens's Oliver Twist (1837-9), workhouse orphan Oliver flees starvation in the provincial Mudfog workhouse for London, "that great place" where "nobody ... could ever find him" (Dickens [1837-9] 2003: 57). The capital, Oliver has come to believe, "was the very place for a homeless boy" because "there were ways of living in that vast city" that ensured that "no lad of spirit need want in London" (Dickens [1837-9] 2003: 57). Oliver eventually "enter[s] London ... [after] nightfall ... [at] the turnpike at Islington" in the company of John Dawkins, the "Artful Dodger" (Dickens [1837-9] 2003: 63). After the setting of the early chapters in the imaginary Mudfog and on the interminable road that signals Oliver's long journey to the metropolis, the text suddenly shifts to cartographic specificity:

They crossed from the Angel into St. John's Road; struck down the small street which terminates at Sadler's Wells Theatre; through Exmouth Street and Coppice Row; down the little court by the side of the workhouse; across the classic ground which once bore the name of Hockley-in-the-Hole; thence into Little Saffron Hill; and so into Saffron Hill the Great.

(Dickens [1837-9] 2003: 63)

Despite their "rapid pace," Oliver is appalled to discover that the streets of London are not, after all, paved with gold:

A dirtier or more wretched place he had never seen. The street was very narrow and muddy, and the air was impregnated with filthy odours.

There were a good many small shops; but the only stock in trade appeared to be heaps of children, who, even at that time of night, were crawling in and out at the doors, or screaming from the inside. The sole places that seemed to prosper amid the general blight of the place, were the public-houses; and in them, the lowest orders of Irish were wrangling with might and main. Covered ways and yards, which here and there diverged from the main street, disclosed little knots of houses, where drunken men and women were positively wallowing in filth; and from several of the door-ways, great ill-looking fellows were cautiously emerging, bound, to all appearance, on no very well-disposed or harmless errands.

(Dickens [1837-9] 2003: 63)

Fifty years later, George Gissing's brutal slum novel The Nether World (1889) revisits the district of Clerkenwell, "a strange enough region wherein to wander and muse" (Gissing [1889] 1992: 11). At the beginning of the novel, elderly Michael Snowdon returns to his native Clerkenwell to look for surviving relatives after a lengthy sojourn in Australia, where he has come by a considerable fortune. "In the troubled twilight of a March evening ten years 
ago," the narrator tells us, situating the beginning of the story in the late 1870s, Snowdon "walked slowly across Clerkenwell Green; and by the graveyard of St. James's Church stood for a moment looking about him" (Gissing [1889] 1992: 1) at the bleak scene in which there was "little restful to the eye ... The small trees that grew about [the graveyard] shivered in their leaflessness; the rank grass was wan under the failing day; most of the stones leaned this way or that, emblems of neglect," while "the east wind blew with malice such as it never puts forth save where there are poorly clad people to be pierced ... on every side was the rumble of traffic, the voiceful evidence of toil and of poverty" (Gissing [1889] 1992: 2). "[W]ith a slight sigh," Snowdon proceeds "along the narrow street which is called St. James's Walk" and finds "himself facing [the] high grey-brick wall" of the Middlesex House of Detention (Gissing [1889] 1992: 2). There he is confronted with the jail's "arched gateway closed with black doors," on top of which stands a

sculptured counterfeit of a human face, that of a man distraught with agony. The eyes stared wildly from their sockets, the hair struggled in maniac disorder, the forehead was wrung with torture, the cheeks sunken, the throat fearsomely wasted, and from the wide lips there seemed to be issuing a horrible cry.

(Gissing [1889] 1992: 2)

An emblem of the blighted lives of the Clerkenwell poor, the effigy sets the novel's tone of despair and aversion towards the "the squalid and toil-infested ways of Clerkenwell" (Gissing [1889] 1992: 51).

The comparison between Dickens's early-Victorian novel, initially serialised in Bentley's Miscellany with illustrations by George Cruikshank and apparently set in the 1820s, and Gissing's late-century Naturalist three-decker, initially published as a library novel by Smith, Elder but soon reissued in 6s., 2s.6d. and 2s. single-volume editions (Devine 2001: 12), demonstrates the generic connections and transitions apparent in Victorian popular fiction, understood here broadly to include cheap lowbrow mass-market publications, genre fiction, periodical narratives blurring the boundaries of fact and fiction, middlebrow fiction in a range of formats that achieved substantial sales, and fiction about "working-class characters in a working-class environment" frequently produced "by authors who are not working class, for an audience which is not working class" (Keating 1971: 2). Dickens and Gissing show awareness of the genre conventions governing the city novel, the Newgate Novel and the slum novel, while also seeking to represent the lives of the Clerkenwell poor for a primarily middle-class audience who might otherwise never have visited the district through narratives that assail all the senses through the sights, sounds, odours and sensations of the area. Each shows a familiarity not only with Clerkenwell and its history (including literary history) of marginality but also with non-fictional discourses about urban poverty, particularly investigative social exploration journalism and early sociological studies. Such generic echoes prove instructive, this special issue of Victorian Popular Fictions Journal suggests, in mapping the development of literary genres and tropes.

The comparison also foregrounds the cartographic impulse at work in Victorian popular fiction itself. Both authors situate their narratives in a specific district of London, Clerkenwell, and map their characters' lives and movements in the area carefully - so carefully, indeed, that it is possible to follow them on an actual map. Not only does this demonstrate how fiction creates textual worlds by emphasising certain characteristics and landmarks, it also suggests that literature could inform public perceptions of - effectively make - real-life locales. The comparison also highlights the association of particular genres with particular kinds of setting, while simultaneously demonstrating that characteristic settings can also help to map the development of and connections between genres. Such 
considerations are intimately related to what Andrew Thacker terms "textual space": plot structure, layout, publication format, possible serialisation and means of distribution (Thacker 2017: n.p.; original emphasis). The journeys undertaken by Oliver and Snowdon indicate the importance of travel and the interconnectedness of space - metropolitan, national, global - in the Victorian literary universe, and journeys and boundary crossings emerge as important drivers of character and plot development. The comparison also spotlights the usefulness of examining a particular place through multiple sources, using the principles of geocriticism (discussed below), distant reading and digital humanities methods, to establish its significance in the Victorian mindset. Finally, the symbolic and subjective readings evident in both texts suggest that the settings of Victorian popular fiction might be as much psychological as physical. As this special issue of Victorian Popular Fictions Journal demonstrates, these spatial considerations are central to Victorian popular fiction.

In recent decades, literary critics have come to pay increasing attention to matters of place, space and mapping, effecting a veritable "spatial turn" in the Humanities (Tally 2013: 12). According to its perhaps foremost current advocate, Robert T. Tally Jr, the field of "spatial literary studies" is "a multiform critical practice that would include almost any approach to the text that focuses attention on space, place, or mapping, whether within the confines of the text, in reference to the outside world, or in some combination of the two" (Tally 2019: 176), and involves "reading literature with a heightened sensitivity to spatial relations, as well as to place and mapping" (Tally 2019: 38). Tally identifies three central approaches to reading literary spatialities: literary cartography, in which the author, guided by genre conventions and subjective vision, creates a literary world; literary geography, in which the reader attempts to comprehend the textual universe; and geocriticism or cartographics, in which a critic charts and analyses literary spaces (Tally 2013). This critical analysis, Peter Brown notes, tends to focus either on 'the 'outside' (literary places)," mapping authors' lives and seeking to establish the relationship between the real world and literary settings, or "the 'inside' (places in literature)," exploring "the idea of place" rather than seeking to identify its correlation to reality (Brown 2006: 13). Some critics working in this field, most notably Franco Moretti, have made use of maps as "tool[s] for literary analysis," but many others, including Tally and Bertrand Westphal, have found little use for visuals, being "primarily ... interested in maps in literature rather than maps of literature" (Mitchell 2017: n.p.).

It is a commonplace of spatial literary studies to assert that the spatial turn is a postmodern and post-war development, prompted by unprecedented human mobility, disruption and the breakup of nations and empires following the Second World War, which indicated that "one's place could not simply be taken for granted any longer" (Tally 2013: 13; original emphasis). However, significant precursors had emerged in the first half of the twentieth century in Sigmund Freud's spatialisation of the mind and conceptualisation of the "uncanny" (1919); Martin Heidegger's notions of "being" and "dwelling" in Being and Time (1927); Walter Benjamin's theorisation of flânerie in The Arcades Project (1927-40); and Mikhail Bakhtin's analysis of space-time, or the chronotope (1937-8). Significant works of spatial theory that emerged in the second half of the twentieth century include Gaston Bachelard's phenomenological, topophilic analysis of the relationship between the house and identity, The Poetics of Space (1958); urban geographer Kevin Lynch's investigation into city planning and pedestrians' cognitive urban mapping in The Image of the City (1960); Raymond Williams's 1973 analysis in The Country and the City; Henri Lefebvre's The Production of Space (1974), which influentially argues that "(Social) space is a (social) product" that "can be read" (Lefebvre [1974] 1991: 26, 17; original emphasis); Michel Foucault's analyses of how space affects behaviour and produces identity in his exploration 
of the panoptic principle in operation in modern society in Discipline and Punish (1975) and of heterotopic spaces in the posthumously published essay "Of Other Spaces" (1986); Edward W. Said's examination of the process of othering of the non-western world in Orientalism (1978); Michel de Certeau's exploration of pedestrians' street-level ownership of the city in The Practice of Everyday Life (1984); and Edward Soja's call for the 'spatialization of the critical imagination' (Soja 1989: 11) and identification of the possibilities of fuzzy "real-and-imaginary" "thirdspace" (Soja 1996: 6) in Postmodern Geographies (1989) and Thirdspace (1996). All of these foundational works of spatial theory tend to argue that space and identity are intimately related and that space is a text to be read.

Building on these early works of spatial theory, more recent developments in the field follow Moretti's contention that "geography is not an inert container ... where cultural history 'happens', but an active force, that pervades the literary field and shapes it in depth" (Moretti [1998] 2011: 3). Moretti's provocative map-making in Atlas of the European Novel, 1800-1900 (1998) and increasingly abstract methods of visualisation and "distant reading" in Graphs, Maps, Trees (2005) and Distant Reading (2013) have challenged literary critics' traditional twin foci of textual and contextual analysis and provided the Digital Humanities and Geographic Information Science with great momentum. Tally's numerous publications, including a number of important edited collections and an excellent, accessible study of Spatiality (2013) for Routledge's New Critical Idiom series, have been instrumental in promoting spatial literary studies in its broadest terms. Tally has also translated the work of the French scholar Westphal, whose interdisciplinary and intertextual theory of geocriticism challengingly maintains that "space cannot be understood except in its heterogeneity" and seeks "to map possible worlds, to create plural and paradoxical maps" "from a spectrum of individual representations as rich and varied as possible" drawing on the key principles of "spatiotemporality, transgressivity, and referentiality ... multifocalization, polysensoriality, stratigraphy, and intertextuality" - essentially an awareness of the connections between a text and place, time, experience and other texts (Westphal [2007] 2011: 37, 73, 113, 122). As this essay will demonstrate, while a geocritical reading can produce powerfully multi-layered readings, it also faces formidable problems in the selection of the corpus.

Spatial theory tends to follow Foucault's assertion that the "present epoch will perhaps be above all the epoch of space," in contrast to the nineteenth century's "obsession" with time, teleology, "history" and "themes of development and of suspension, of crisis and cycle" (Foucault 1986: 22). However, the nineteenth century, too, experienced its structural ruptures and spatial shifts in unprecedented urban growth, imperial expansion, more effective travel and new communications technologies, concerns over immigration, and the restructuring of established gendered spheres (Vuohelainen 2015: 10-11). As the essays in this special issue demonstrate, nineteenth-century literature and popular culture were acutely aware of questions of space, place and mapping, and representative nineteenth-century genres such as domestic realism, the city novel, the Gothic, the adventure romance and science fiction are intimately concerned with delineating a set of characteristic spatialities. Indeed, many nineteenth-century authors such as Charles Dickens, the Brontës, Anthony Trollope, Thomas Hardy and Hall Caine developed reputations specifically as authors of local or regional fiction, and many popular texts of the period were accompanied by maps or diagrams such as those found in Hardy's The Return of the Native (1878) and subsequent "Wessex Novels," R. L. Stevenson Treasure Island (1882), H. Rider Haggard's King Solomon's Mines (1885), or Arthur Morrison's slum novel A Child of the Jago (1896). Literature of urban observation and investigation, epitomised in Charles Baudelaire's notion of flânerie (later theorised by Walter Benjamin), the social exploration journalism of writers such as Henry Mayhew, James 
Greenwood, W. T. Stead and Jack London, and the urban detective fiction of Arthur Conan Doyle and his imitators represents another form of literary mapping characteristic of the period. At a time of increased leisure spending, this attention to place prompted the growth of literary tourism and led to the publication of the first studies of literary geography in the form of, among others, the "Literary Map" prepared by William Lyon Phelps in 1899 and published in textbooks such as William J. Long's English Literature: Its History and Significance (1909), William Sharp's Literary Geography (1904), which was accompanied by maps and illustrations, and guides to the Hardy Country by Charles G. Harper (1904) and Hermann Lea (1906).

Nineteenth-century popular fiction, then, evidences what Tally calls "a persistent placemindedness" or "topophrenia" (Tally 2019: 1-2). "Mapping," Tally suggests, "may be seen as an activity not unrelated to literary production" (Tally 2019:2). Indeed, this attention to space and place characterises both reading and writing, for a story, according to Tally, "is simultaneously something that maps and something to be mapped" (Tally 2014: 3). Fictional worlds often combine examples of "the real places of the geographical globe and the imaginary places of [the author's] own fictional universe" (Tally 2013: 45), while readers engage in "cognitive mapping" (Ljungberg 2017: n.p.) that may require a conscious adjustment, for example to an alternative universe, but may also "help to shape the spaces and places we perceive, experience, and inhabit" (Tally 2019:4) or even to "orient ourselves in real space by recourse to an imaginary one" (Dennis 2017: n.p.).

The essays in this special issue identify multiple ways in which such mapping Victorian popular fictions that map, and that can themselves be mapped - operates. Tabitha Sparks charts the spatial tropes evident in nineteenth-century and modern-day critical responses to middlebrow women authors, noting the nineteenth-century tendency to situate them within domestic settings and modern-day feminist scholars' subsequent difficulties, apparent in a tendency towards surface or distant reading, in placing middlebrow writing that conforms rather than subverts. Tamara S. Wagner maps tropes of homemaking and homecoming in female-authored Australian and New Zealand settler fictions, which together influenced expectations of settler life for readers in the imperial centre. Luisa Villa explores how the Sudanese military adventure story was shaped by, and in turn shaped, the perception of the Sudanese territory and people in the late century, charting the development of a location-specific subgenre of popular fiction. Rebecca Nesvet reads The String Pearls to recover its lost Indian contexts, questioning the now common reading of this penny blood as a characteristic London text and discussing the remapping of contemporary ideas and concerns that popular culture commonly performs. Sophie Raine's analysis of the penny dreadful The Young Ladies of London establishes a shift from erotic voyeurism to socially conscious commentary on urban prostitution, with the narrator and prostitute-characters guiding the reader on a vicarious tour of London's brothels that is eventually seen to subvert the panoptic principles in operation at the start of the narrative. Samuel Saunders charts the development of the little known fictional mid-century police memoir as an urban genre that explored the relationship between the police and the city's criminal underbelly, demonstrated the police's extensive but partial knowledge of the city, and paved the way for the emergence of serial detective fiction. Claire Whitehead's reading of the multiple, genre-specific spatialities of nineteenth-century Russian crime fiction establishes that genre conventions travel between different kinds of popular fiction and between countries, and demonstrates how popular authors such as Semyon Panov, the focus of her essay, deployed, troubled and reworked established genre conventions. Andrew Hewitt's exploration of fictional maps in the work of Richard Jefferies and Anthony Trollope questions the established Foucauldian 
paradigm that maps are invariably tools of power by arguing that some maps may articulate affection for places, real and imaginary, that have been important to us and have made us who we are. Michael Horton mines digital newspaper archives to map the appearance of monsters in nineteenth-century "weird news," news items about supposed monster sightings, in an essay that argues that the Victorians' fascination with the otherworldly was largely articulated in newsprint and genre fiction. Shuhita Bhattacharjee explores the notion of the cartography of the supernatural in her analysis of the representation of occult Theosophic spatialities in two late-Victorian novels that challenge western orthodoxies by suggesting the liberating potential of alternative eastern faiths. This introduction, finally, tests Westphal's call for polysensorial, intertextual, multifocal geocentric readings alive to the referentiality, spatiotemporality and transgressivity of literary space by exploring a range of nineteenthcentury texts set in the London district of Clerkenwell. My corpus, which is not intended to be and indeed could not be exhaustive, includes fiction by Dickens, Gissing, George W. M. Reynolds, George du Maurier and Amy Levy, Charles Booth's maps of the area, and journalistic explorations of the area. Between them, the essays in this special issue map real and imaginary spaces, the tropes of domesticity, incarceration and travel, the development of genres and genre conventions, the spatial representation of social relations, and the media and methods of reading and researching Victorian popular fictions.

\section{Mapping Genre}

As the essays in this special issue demonstrate, Victorian popular fiction tends to comprise genre fiction. Apart from the Newgate, slum, penny, realist, short and occult fiction, maps and journalism considered in this introduction, the essays collected here offer examples of the penny blood and the penny dreadful (Nesvet and Raine), crime and detective fiction (Saunders and Whitehead), journalism (Sparks and Horton), domestic fiction and realism (Wagner and Hewitt), and adventure and the occult (Villa and Bhattacharjee). In each and every case, the generic boundaries are found to be porous: the police memoirs considered by Saunders, for example, owe much to investigative journalism, bleed into detective fiction and blur the boundaries between fiction and memoir, while the military adventure stories explored by Villa are intimately related to earlier boys' adventure stories, war reportage, the Imperial Gothic and later invasion fiction. Mapping such inter-generic connections is one of the key foci of this issue and indeed of the study of Victorian popular fiction in general.

Genre itself is a spatial matrix. As John Frow notes, genre fiction tends to draw on formulas and conventions that are recognisable to authors and readers alike (Frow 2006: 1, 69). These shared conventions allow genre to function, according to Tally, as "a sort of map" or "a guidebook" that can help both authors and readers to orientate themselves in the literary universe (Tally 2013: 55-6). These textual worlds, Frow contends, are "always, and by definition, generically specific," even if "they may overlap with others," as the essays in this issue demonstrate that they frequently do (Frow 2006: 76, 18). Different genres "represent reality in particular, identifiable, and distinctive ways" that "project a world" that is specific to them (Tally 2013: 59, 55). Moretti's literal mapping of nineteenth-century fiction leads him to conclude, similarly, that "[e]ach genre possesses its own space" and, more controversially, "each space its own genre" (Moretti [1998] 2011: 35; original emphasis). This latter statement suggests that not only does generic framing shape our interpretation of the textual universe but that our familiarity with genre conventions may lead us to perceive particular spaces in the real world in specific ways. 
As we have already seen, critics tend to agree that nineteenth-century realism lends itself particularly well to cartographic literary study (Schilling 2014: 216) because of its preference for real-world locations, "tangible, architectonic and (by and large) mappable," over imaginary ones (Brown 2006: 17). Gissing's The Nether World, often read as a realist or Naturalist novel, demonstrates this well. Emma Liggins notes Gissing's "commitment to realism and the urge to develop the British urban novel by faithfully representing scenes he witnessed every day in the back streets of London" (Liggins 2006: 59), and reviews of The Nether World emphasised its "terrible realism" (Contemporary Review, in Coustillas and Partridge 1972: 142) and ability to transport "readers to Clerkenwell" where they "move, shuddering, with the author, through an atmosphere fetid with all the abominations of life in the slums" (Court Journal, in Coustillas and Partridge 1972: 137). As Liggins observes, Gissing researched his topic in great detail by exploring contemporary streets, places of work and sociological writings to support his vision of the district (Liggins 2006: 32), but the evocation of Clerkenwell as a dark, menacing "nether world" or even "Hell!" (Gissing [1889] 1992: 8, 345), epitomised by the silent scream of the effigy on the prison gate, also resonates uncannily with both Dante's Inferno, categorically a work of canonical high culture, and with popular Urban Gothic fiction, which in the same period represented London as an ominous labyrinth inhabited by monstrous beings (see Vuohelainen 2015, chapter 1). Far from some unmediated photographic copy, therefore, the novel offers "a personal vision" of an urban district that is "both a physical and a spiritual landscape" (Spiers 2006: 1, 6). Gissing was himself aware that his representation would be subjective. In a letter to Thomas Hardy in July 1887 , he wrote of his "hope to turn to some vigorous purpose, a story that has grown up in recent ramblings about Clerkenwell" (Gissing 1992: 139), while in an 1895 essay on "The Place of Realism in Fiction" he asserted that "every novelist beholds a world of his own, and the supreme endeavour of his art must be to body forth that world as it exists for him" (quoted in Gill 1992: x). This "subjective vision" (Hutcheon 2018: 8) was informed by Gissing's prior reading and urban rambles, moulded the textual world of his novel, and has since "shaped how we see and experience "the city" (Spiers 2006: 1).

Often seen as "the nadir of [Gissing's] social and cultural vision" (Moore 2008: 5), the generic roots and subsequent offshoots of The Nether World demonstrate well the intricate connections that characterise generic maps. Liggins observes that Gissing's "extensive ramblings [in Clerkenwell] were supplemented by careful reading of contemporary sociological discourses about work and urban life, with details ... drawn from Arnold White's Problems of a Great City (1886)" (Liggins 2006: 32). In locating the novel in Clerkenwell, however, he effects a significant shift in the genre of the slum novel by deliberately "disrupting the East End/West End binary" that characterises much lateVictorian urban writing (Devine 2001: 7). As Liggins explains, he may have been "unconsciously emulating the French novelists to whom he had been compared" such as Émile Zola (Liggins 2006: 31). In its focus on a largely self-contained district that functions as a post-Darwinian laboratory in which characters are left to interact, survive or perish, the novel also obliquely recalls Hardy's Wessex novel The Woodlanders, which had been serialised in Macmillan's Magazine in 1886-7. Gissing repeatedly discussed The Woodlanders in his correspondence with his brother Algernon and with Hardy himself, apparently in high anticipation (Gissing 1992: 42, 100, 138), but eventually dismissed it rather pettily as "surprisingly weak" (Gissing 1992: 233).

Gissing's most important influence, however, was Dickens, a writer who for many readers still is synonymous with London (Baumgarten 2008: 117) and who "found his creative energy" in "walking all over the city" (Humpherys 2011: 231-2). As Rebecca 
Hutcheon notes, Gissing, originally from Wakefield, "approaches London as a reader," conscious of Dickensian echoes and the author's shadow in his own responses to the city and painfully aware of his own sense of "secondariness and an anxiety of influence" (Hutcheon 2018: 64-5). The Dickensian echoes are present in the novel's protagonists: the gentle, vulnerable child, Jane Snowdon; the innately noble artisan, Sidney Kirkwood; Michael Snowdon, the colonial returnee with a secret fortune; the brutal, animalistic Clem Peckover, "a rank, evilly-fostered growth" sprung from the "putrid soil of that nether world" (Gissing [1889] 1992: 8) whose very name evokes Dickens. They are also evident in the plot's promise of a miraculous fortune and escape, in the connections suggested between Clerkenwell and other, wealthier parts of London (Moretti [1998] 2011: 124-33), and in the sense of a "profound attraction of repulsion" towards scenes of low life (Forster 1872: 19). However, as Stephen Gill observes in his introduction to the Oxford World's Classics edition, The Nether World "continually invokes Dickens only to subvert the Dickensian" (Gill 1992: xix): there is no happy ending for Jane and Sidney, though Gissing described the novel as "dark, but with evening sunlight to close" (Gissing 1992: 139); the inheritance plot is deployed "only for the sake of irony" (Hertel 2004: 21); and "no escape" is possible from the "state of punishment" and the "want and misery" of Clerkenwell (Gissing [1889] 1992: 345). These distorted echoes of Dickens are indicative of the mutations of the urban novel between the 1830 s and the 1890 s. $^{1}$

The sense of inevitability and incarceration that marks The Nether World also pervades Amy Levy's short story "Eldorado at Islington," published in Oscar Wilde's middle-class women's shilling monthly, the Woman's World, in July 1889. The story, told largely from the perspective of lower-middle-class Eleanor Lloyd, experiencing "fits of longing, ... yearnings for happiness" while "caught ... in a pitiless network of suburban streets" just off Islington High Street, holds out and then withdraws the promise of a miraculous inheritance bequeathed by the estranged brother of Eleanor's "[h]ard-working, unassuming, delicately just" father (Levy [1889] 2006: 228). In "showing ... sympathy for the "small bourgeoisie" (Beckman 2000: 186), Levy shifts the focus of Clerkenwell fiction from the working poor to a lower-middle-class female consciousness, gesturing towards the New Woman short story, and the "unutterable tedi[um]" of "ignobly decent life" that would be a central concern in New Grub Street (1891), Gissing's novel about the hardships of literary labour in an increasingly professionalised and rapidly evolving market for the "quarter-educated" (Gissing [1891] 1999: 460). In the later novel, the doomed author Harold Biffen advocates "an absolute realism" that "treat[s] ordinary vulgar life with fidelity and seriousness," rejecting both the "deliberate tragedies" of Zola and Dickens's "tendency to melodrama," "absurdity" and "humour" (Gissing [1891] 1999: 144-5). The germs of the 1891 novel are perhaps already present in The Nether World, however, in the "memories ... revived" in the narrator by the sight of St John's Arch, "a survival from a buried world - the embattled and windowed archway which is all that remains above ground of the great Priory of St. John of Jerusalem" (Gissing [1889] 1992: 51). Notably more cultured than his characters, the narrator recalls that the gateway used to be home, "a hundred and fifty years ago, [to] one Edward Cave, publisher of the Gentleman's Magazine, and there many a time has sat a journeyman author of his, by name Samuel Johnson, too often impransus" (Gissing [1889] 1992: 51). Yet these educated reflections on the empty stomach of Dr Johnson, whose dictionary defines "grubstreet" as the "mean production" of "writers of small histories, dictionaries, and temporary poems" (Johnson [1755] 1994: 329), lead the narrator not to perceive a connection

\footnotetext{
1 The essays by Wagner, Villa, Saunders and Whitehead mark similar generic shifts in other nineteenth-century genres.
} 
between the past and the present plight of Clerkenwellians but to remark that "this monument of old time ... sad, worn, grimy ... looks depressed, ashamed, tainted by the ignobleness of its surroundings" (Gissing [1889] 1992: 51), perhaps foreshadowing Gissing's imminent transition from an author of working-class life to one dealing with various degrees of middleclass precariousness. Three decades later, Arnold Bennett's Riceyman Steps (1923) would develop similar themes of lower-middle-class tedium in Islington.

Slum fiction was not, however, the only possible generic outcome of Clerkenwell fictions. As V. A. C. Gatrell notes, the "scaffold loomed large in the popular imagination" at a time of unprecedented criminal law reform (Gatrell 1994: 112). In the 1830s, Dickens's Oliver Twist was read in the context of the phenomenal popularity of the Newgate novel, a genre that glamorised dashing criminal protagonists, critiqued the harshness of the penal code and offered "a primary platform for the articulation of recent experiences of poverty, solitude, and loss of family" (Buckley 2002: 431). While Dickens disagreed with the perception of Oliver Twist as a Newgate novel, its kinship with the genre was foregrounded by its connections with William Harrison Ainsworth's phenomenally successful Jack Sheppard. Both texts were serialised in the upmarket 2s.6d. Bentley's Miscellany, with the beginning of Jack Sheppard (1839-40) overlapping with the final instalments of Oliver Twist (1837-9); furthermore, Ainsworth assumed the editorship of Bentley's from Dickens, while the celebrated artist George Cruikshank illustrated both serials (Hollingsworth 1963: 131). Ainsworth's novel was itself a potent generic mixture of historical, fictional and artistic sources about the real Jack Sheppard (1702-24), a notorious burglar whose sensational prison breaks, discussed later, had turned him into a celebrity and who, with his antagonist Jonathan Wild, was among "the star-turns of the various compilations of criminal lives known collectively as The Newgate Calendar," a significant early form of crime fiction (Priestman 1998: 34). As Ruth Baldwin notes, Ainsworth was keen "to highlight his novel's connection with earlier narratives of Sheppard's life" and "consolidates the disparate strands of Sheppard lore" to create "a coherent criminal history" from "popular fictions and folk legends" (Baldwin 2013: 246, 241, 249). Ainsworth's combination of creative reimagining, breathless narrative excitement and "meticulous" interest in "the condition of Newgate and ... historic locations" (Hollingsworth 1963: 136) "helped to redefine the form and cultural work of the historical novel in the early Victorian period" (Baldwin 2013: 237), but the "degree of primacy, licence, and pleasure" the genre "accorded ... to the exploration of criminality" (Gillingham 2009: 885) also points forward to the sensation novel and its twin offspring, lateVictorian Gothic and detective fiction. The Newgate genre's stock device, the inheritance plot, foregrounds this generic transfer. ${ }^{2}$

Ainsworth's novel, Keith Hollingsworth notes, "was not simply a sensation in fiction, but an extra-literary popular phenomenon" (Hollingsworth 1963: 140). One medium that guaranteed Jack Sheppard's extraordinary success was its adaptation for the stage. By autumn 1839, no fewer than eight stage adaptations were on offer in London. One of these, by Thomas Greenwood, opened on 28 October at Sadler's Wells in Clerkenwell (Hollingsworth 1963: 139), a quarter of a mile from where the New Prison, the site of one of Jack's escapes, had stood, and just over a mile from Newgate itself. Long the haunt of criminals, Clerkenwell was a peculiarly apt place to stage Jack's adventures.

\footnotetext{
${ }^{2}$ The essays by Nesvet and Whitehead below chart generic developments in penny and crime fiction, while Wagner traces the inheritance plot in settler fictions.
} 


\section{Mapping Place}

The parish of Clerkenwell, tantalisingly situated east of affluent Bloomsbury, west of the East End and north of the financial City of London, has traditionally been seen as "the harbour for the outcast and those who wished to go beyond the law ... the home of groups who wish to be separate and separated" and "a catchment area of dissent and possible radical disruption" (Ackroyd 2000: 463, 465). As Peter Ackroyd observes, "there was a strong emphasis on official surveillance" in this area that was "a known centre of radical activity" (Ackroyd 2000: 466). Once fashionable because of its health-restoring springs, the district was, by the nineteenth century, perceived as a hive of radicalism and political gatherings on the Green and in the public houses lining it. A successful local halfpenny paper, Clerkenwell News, sold "upwards of 40,000" copies per week, spread over two weekly issues (Pinks [1863-5] 1881: 173). According to an article published in All the Year Round in 1872, the paper was particularly notable for the number of job advertisements it carried for women in artificial flower making, millinery, tailoring and dressmaking, which "impos[ed] ... less restraint on personal liberty" than domestic service ("Wanted in Clerkenwell" 1872: 251-2). The population of the district grew rapidly from 23,396 inhabitants in 1801 to 69,076 in 1881 (Temple 2008: n.p.); at the mid-century, two-thirds of Clerkenwellians were born Londoners, but the area was also home to significant migrant communities of Irish, French, Italian and German immigrants (Pinks [1863-5] 1881: 14, 592). It was closely associated with beer breweries, gin distilleries and the sale of meat from the nearby Smithfield. Dickens's Pip in Great Expectations was not alone in finding the notorious meat market a "shameful place, being all asmear with filth and fat and blood and foam" (Dickens [1860-1] 1999: 131): its "mud, curses, and cries of ill-treated animals" left such an indelible impression on a young Thomas Hardy, staying with his mother at the Cross-Keys coaching inn in St John's Road, once the site of assignations between Percy Bysshe Shelley and Mary Godwin, that eighty years later he left money in his will for promoting humane methods of transporting animals to slaughter-houses (Hardy [1928-30] 2007: 18, 445). Oliver's experience of the market is of "a stunning and bewildering scene, which quite confounded the senses" with its "hideous and discordant din" (Dickens [1837-9] 2003: 171). These sensory impressions are closely aligned.

Above all, however, Clerkenwell was associated with the manufacture of clocks, watches and jewellery, skilled artisans producing luxury goods they could never themselves afford to purchase. As Gissing puts it,

Go where you may in Clerkenwell, on every hand are multiform evidences of toil, intolerable as a nightmare ... every alley is thronged with small industries; all but every door and window exhibits the advertisement of a craft that is carried on within ... Workers in metal, workers in glass and in enamel, workers in weed, workers in every substance on earth ... are for ever handling jewellery, shaping bright ornaments for the necks and arms of such as are born to the joy of life. Wealth inestimable is ever flowing through these workshops, and the hands that have been stained with gold-dust may, as likely as not, some day extend themselves in petition for a crust.

(Gissing [1889] 1992: 10-11)

However, the district was also defined by the visible presence of disciplinary institutions: the Old Sessions House where the Middlesex Quarter Sessions were held on Clerkenwell Green, which had historically been a site of torture and execution, the Middlesex House of Detention (demolished in 1890), Coldbath Fields Prison (replaced by Mount Pleasant Post Office in 1889), and Newgate itself to the south of Smithfield. 
None of the literary texts set in Clerkenwell discussed here originally contained an actual map of the district. However, "a map may also constitute itself in words" (Tally 2013: 46), as mapping can operate both "in literal ways by surveyors, architects, builders, cartographers; and in more figurative ways by novelists, journalists, sociologists, government investigators" (Joyce 2003: 4). ${ }^{3}$ Clerkenwell fictions demonstrate a significant degree of awareness of the topography, character and history of the area. As F. S. Schwarzbach notes, the "details" of Oliver's journey "are scrupulously accurate - every street and turning is carefully and exactly named" - so much so that "every detail can be placed on a map" (Schwarzbach 1979: 46, 48). Similarly, a number of critics have noted the cartographic qualities of Gissing's work. Richard Dennis observes that "Gissing is very precise in this choice of London locations" (Dennis 2010: 2), while Michael Irwin registers the novel's "topographical scrupulosity" and "documentary exactness" (Irwin 2006: 32). For Stephen Gill, "Gissing's use of real names of streets and buildings invites the reader to look at a map" (Gill 1992: 393, n. 2), while Susan Cook, commenting on the novel's "documentary-like sense of immediacy," posits that the text seems "intended to evoke a verbal map" (Cook 2009: 464). Rebecca Hutcheon foregrounds Gissing's "acute sensitivity to place," "toponymic and topographic authenticity" and "frequent use of tangible and known locations, real place names, scrupulous attention to topography and locodescriptive set pieces" (Hutcheon 2018: 1, 3-5).

In his capacity as journalist and social explorer, Dickens accompanied police officers on their nocturnal rounds and visited workhouses, publishing his investigative work in his $2 \mathrm{~d}$. weekly Household Words (1850-9) to promote his progressive social agenda. ${ }^{4}$ Gissing's work, similarly, "draws comparison" (Hutcheon 2018: 67) and "resonates with contemporary" sociology (Cook 2009: 461), particularly Charles Booth's monumental social survey The Life and Labour of the People in London (1886-1903), which included a set of Maps Descriptive of London Poverty. Often used to illustrate studies of the Victorian city, these maps have attracted relatively little attention in their own right as a significant aid to the study of late-Victorian urban literature. Booth, a wealthy shipping merchant from a Liberal, Unitarian Liverpool family, had embarked on what has been described as "probably the largest private inquiry ever undertaken" (Englander and O'Day 1997: 6) in 1886 after reading an article in the Pall Mall Gazette that claimed that 25\% of London's population were living in poverty. A social reformer who distrusted both philanthropy and socialism (Orford et al. 2002: 26), Booth wished to disprove empirically what he saw as unfounded and unscientific allegations and instead sought "to establish the truth about the condition of the people in London as a necessary prelude to the discovery of appropriate remedies" (Englander and O'Day 1993: 19). The result is a characteristically ambitious Victorian endeavour: over the course of seventeen years, Booth's team of more than thirty "professional or semiprofessional researchers" (Englander and O'Day 1993: 12), mainly university-educated men and women with links to university settlements, statistical societies and philanthropic causes (Englander and O'Day 1995: 27), evaluated a wealth of material consisting of questionnaires, reports, personal observation, statistical data, and interviews (Englander and O'Day 1993: 18) with volunteer observers deemed to have a good (but not necessarily unbiased) personal knowledge of the areas under consideration: school board visitors, teachers, policemen, clergy, social workers and local administrators (Reeder 1995: 326). Between 1886 and 1891,

\footnotetext{
3 Hewitt, Nesvet, Villa, Saunders and Horton identify a cartographic impulse that operates independently of visual maps in Victorian popular fiction.

${ }^{4}$ Raine and Saunders trace similar convergences between urban genre fiction and investigative social exploration journalism.
} 
the team covered a staggering 13,600 London streets in a bid to understand the character of the city (Englander and O'Day 1993: 44); and in 1897-8 they revised and extended their earlier evaluations. The findings were published piecemeal, beginning in 1887 with a pilot study of the East End; then a two-volume edition covering the whole of London in 1889-91; and finally, between 1892 and 1903, a 17-volume edition.

The survey adopted "a subsistence definition of poverty" (Englander and O'Day 1997: 5), introducing the concept of the "poverty line" (Simey and Simey 1960: 184; Kimball 2006: 357) and dividing London's population into eight categories ranging from A ("occasional labourers, loafers and semi-criminals") to $\mathrm{H}$ (upper-middle class and above), according to income. Groups A-D, encompassing 30.7\% of Londoners, Booth estimated as living in poverty (Booth [1902] 1969: vol. 2, 20-1). These divisions were then conveyed visually in maps that colour-coded the city street by street, creating what Miles Kimball evocatively describes as "a particular visual representation of London - a painting of the city made with a multitude of tiny strokes, the pointillist lines, dots and dashes of color combining to make a general impression of the metropolis" (Kimball 2006: 370). Based on Ordnance Survey maps, the poverty maps were drawn on a scale of 25 inches to a mile, hand-coloured, and reduced for printing by the specialist map maker Stanford's Geographical Establishment (Kimball 2006: 365). The maps are made unique by the combination of the enormous scale of the project and their minute level of detail, but also by their novel use of colour instead of the established method of gradation shading (Kimball 2006: 366). Figure 1 shows that the eight classes identified in the survey were mapped against a set of six colours, with the middling classes $\mathrm{C}-\mathrm{D}$ and $\mathrm{E}-\mathrm{F}$ combined into light blue and pink, respectively, with the colour purple representing mixed streets. In the heyday of the New Imperialism when the poor were often represented as a race apart, the allocation of black to "vicious, semi-criminal" population unlike the other categories not a subsistence definition - can be seen as racially charged (Reeder 1995: 325). In this replication of the tropes of darkness and unknowability that characterised depictions of London in this period (Kimball 2006: 366), also witnessed in Dickens and Gissing's depictions of London as a dark pit, the maps arguably reveal their "ideological" function as servants of "structures of power or domination" (Tally 2013: 25) and their attempt "to discipline and master" seemingly chaotic urban space (Osborne and Rose 2004: 215).

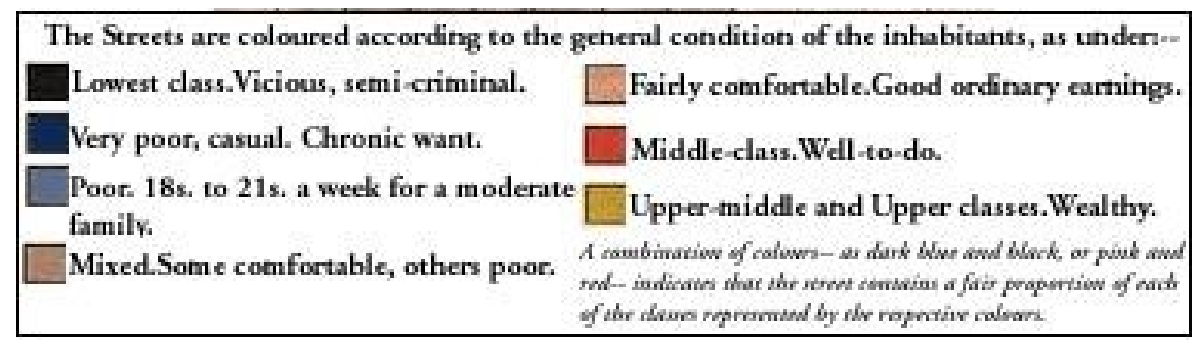

Figure 1. Key to Charles Booth's poverty maps. Source:

https://upload.wikimedia.org/wikipedia/commons/3/3c/Booth_poverty_map_colour_key.jpg

Booth's maps represent Clerkenwell as a mixed area containing significant pockets of poverty that was difficult to categorise and that was also changing in the course of the 1890s. The borough of Finsbury, where Clerkenwell was located, was according to Booth poorer than average, with 35.5\% of the population living under the poverty line (Pfautz 1967: 57). By the late 1890 s, the predominant colour is pink ("Fairly comfortable. Good ordinary earnings"), but there are significant areas that are coloured purple ("Mixed. Some 
comfortable, others poor") or shaded to indicate mixed streets. However, there are also concentrations of streets coloured light blue ("Poor. 18s. to $21 \mathrm{~s}$. a week for a moderate family") and dark blue ("Very poor, casual. Chronic want"), sometimes shading into black ("Lowest class. Vicious, semi-criminal"). A few are coloured red ("Middle class. Well-todo"), but none are yellow ("Upper-middle and Upper classes. Wealthy"). The predominant impression is of an area that is significantly and even confusingly mixed but not living in abject poverty and endemic criminality.

Gissing is known to have perused the first volume of Booth's survey in the British Museum in 1890, and in 1893 struck up a "close friendship with Clara Collet," one of Booth's investigators; however, these dates after the publication of The Nether World preclude any "direct influence" of Booth's survey on the novel (Liggins 2006: xiii-iv). ${ }^{5}$ Placing the novel's central settings on Booth's map (figure 2) demonstrates that Gissing locates radical oratory, street fighting, alcoholism, domestic misery and violence with great care within a very small space in what he terms "the densest part of Clerkenwell," largely around the Green (1) (Gissing [1889] 1992: 232). A site of "fervent, if ungrammatical, oratory" (Gissing [1889] 1992: 53) and of brutal street fighting, the Green first appears at the beginning of the novel as the site of Michael Snowdon's ruminations. Just to the north stands the former gateway of the Middlesex House of Detention with its agonised effigy (2). At this stage, Clem Peckover and her mother keep a "black and cavernous" lodging house in Clerkenwell Close (3), where the Hewitt family rent rooms and Jane Snowdon slaves away as a servant. The noble-minded Sidney Kirkwood resides at the "cleaner end" of Tysoe Street (4), "a short street, which, like so many in London, begins reputably and degenerates in its latter half," where he has a view of the "open space" of Wilmington Square, "grateful in this neighbourhood" (Gissing [1889] 1992: 50). However, Sidney soon has to relocate to less salubrious and more cramped lodgings in Red Lion Street (5), near his work in St John's Square (6), an "irregular" square with "such a number of recesses, of abortive streets, of shadowed alleys, that from no point of the Square can anything like a general view of its totality be obtained" but where "the sordid struggle for existence" is ever apparent (Gissing [1889] 1992: 51). The move from near the regular, open space of Wilmington Square to the confused, cramped cityscape further south physically maps Kirkwood's social decline. The Hewitts later live in the Farringdon Road Buildings (7), erected in 1874 by the Metropolitan Association for Improving the Dwellings of the Industrious Classes (Dennis 2006: 49). Described spitefully as "terrible barracks ... millions of tons of brute brick and mortar, crushing the spirit as you gaze," the Farringdon Road Buildings nonetheless represent an improvement on the Hewitts' previous home, "a kitchen in King's Cross Road" (8) (Gissing [1889] 1992: 274, 186).

The Peabody Estate built in 1884 (9) is the likeliest site for the novel's slum, the "black hole" of Shooter's Gardens, which the narrator tells us has been "of late transformed" by "demolition and rebuilding" (Gissing [1889] 1992: 113, 74). The cartographic absence of this one location, the most squalid of any in the novel, troubles the novel's truth claim while spotlighting Gissing's subjective vision and generic keynotes. Shooter's Gardens may have been modelled on the historic slum in the Turnmill Street area known as "Jack Ketch's Warren," or, tellingly, the "Little Hell," which features in earlier literature of urban exploration as a mysterious thieves' den. George W. M. Reynolds's sensationally successful penny blood The Mysteries of London (1844-5, and continued by other authors for another ten years) commences in a "labyrinth of narrow and dirty streets" in "this horrible

5 Booth was also aware of Gissing, and commended his earlier novel Demos (1886), an acknowledgement which Gissing found "gratifying" (quoted in Hutcheon 2018: 66). 
neighbourhood" where "hideous poverty and fearful crime" hold sway (Reynolds 1846: n.p.), with an unintentional visit to the "curious habitation" in West Street known as the "Old House" or "Jonathan Wild's house" with "dark closets, trap-doors, sliding-panels, and secret recesses" (Pinks [1863-5] 1881: 355). In his sensational journalism, celebrated investigative reporter James Greenwood, the "amateur casual," describes the "horrors" (Greenwood 1874: 57) of these "vile nests ... swarm[ing] with thieves of every degree" (Greenwood 1869: 77) as "a disgrace" (Greenwood 1874: 71). Perhaps indebted to such previous, generically very different texts, Gissing depicts Shooter's Gardens thus: "the walls stood in a perpetual black sweat; a mouldy reek came from the open doorways; the beings that passed in and out seemed soaked with grimy moisture, puffed into distortions, hung about with rotting garments" (Gissing [1889] 1992: 74). This is the home of the Candy family, and later of Pennyloaf and Bob Hewitt, whose courtship in Myddelton Passage (10), "a narrow paved walk between brick walls seven feet high" located "away from the denser regions of Clerkenwell" (Gissing [1889] 1992: 76-7), foreshadows their miserable marriage, first in Shooter's Gardens and later in Merlin Place (11); meanwhile, Pennyloaf's alcoholic mother remains in Shooter's Gardens and purchases her beer in nearby Rosoman Street (12).

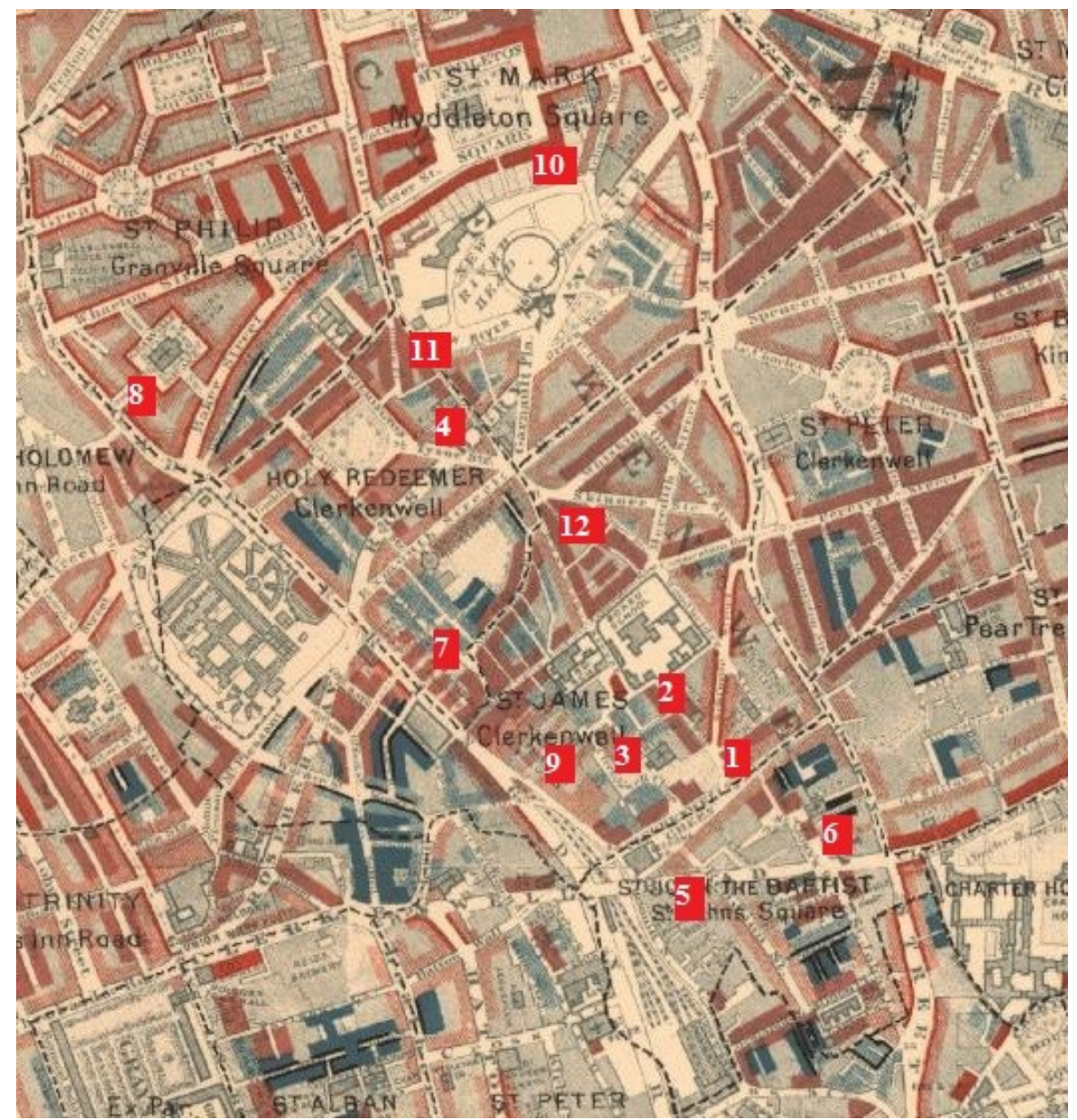

Figure 2: The Clerkenwell settings of The Nether World:

1) Clerkenwell Green 2) The former gateway of the Middlesex House of Detention (now board school) 3) Clerkenwell Close 4) Tysoe Street 5) Red Lion Street 6) St John's Square 7) Farringdon Road Buildings 8) King's Cross Road 9) The likely site of Shooter's Gardens (now Peabody Estate) 10) Myddelton Passage 11) Merlin Place 12) Rosoman Street

Source: Author, created using Charles Booth's London: Poverty Maps and Police Notebooks. 2016. https://booth.lse.ac.uk. Licenced under Creative Commons Public Domain Mark 1.0. 
A comparison with Booth's map demonstrates the narrowness of the novel's geographic compass within a quarter of a mile of Clerkenwell Green. Yet whereas Gissing describes the district as barely human, Booth's maps show a mixed palette of pink, purple and light blue, indicating a lower-middle-class, poor and mixed population rather than outright brutality or criminality. Without vouching for the objectivity and truthfulness of Booth's maps, the comparison is nonetheless instructive in qualifying Gissing's subjective vision and creative licence, and demonstrating the close relationship between genre (slum fiction) and space (the urban nether world) - an example of "[n]arrative [as] "a form of world-making" (Tally 2013: 49). The comparison may, however, also visualise the rapidness with which Clerkenwell was changing in the late century as a result of social reform and slum clearance. The notebooks of George Duckworth, one of Booth's investigators who toured the area in 1898, repeatedly record impressions of "general improvement" and "decided betterment" (Duckworth 1898: 139, 95), while Booth himself described the survey as a "study of a city in motion" (quoted in Pfautz 1967: 121).

\section{Mapping Impressions}

Clerkenwell, then, appears to have produced particular expectations in authors, who were themselves readers. In The Image of the City (1960), the urban geographer Kevin Lynch seeks to understand how urban dwellers read the cityscape. Lynch argues that successful urban environments are characterised by their "legibility" or "imageability": "that quality in a physical object which gives it a high probability of evoking a strong image ... that shape, color, or arrangement which facilitates the making of vividly identified, powerfully structured, highly useful mental images of the environment" (Lynch 1960: 2, 9). Lynch argues that "a distinctive and legible environment" "whose districts or landmarks or pathways are easily identifiable and are easily grouped into an over-all pattern" contributes to a positive urban experience by promoting feelings of "security" and "individual growth" (Lynch 1960: 3-5). Imageability enables "wayfinding," the structured and knowledgeable navigation of the cityscape, with the help of five organising principles or "image elements": paths, established routes through the city; visible landmarks, which aid orientation; edges, which mark borders and boundaries; districts with their distinctive character; and nodes, notable points of meeting, lingering or convergence (Lynch 1960: 3, 8). A high concentration of these features, Lynch argues, results in "an imageable landscape: visible, coherent, and clear," in which the pedestrian feels comfortable; by contrast, a city lacking in imageable elements generates feelings of "fear," "anxiety and even terror" (Lynch 1960: 91, 5, 4). ${ }^{6}$

An examination of literary and journalistic representations of nineteenth-century Clerkenwell complicates this picture by conveying a sense of a district with a distinctive identity, clear edges and recognisable landmarks and nodes, but with confusing paths and, overall, a repellent impact on the outside observer - what might be termed negative imageability. Early in the century, the district features as Oliver Twist's nocturnal gateway to London in the passage quoted at the beginning of this essay. While Dickens maps Oliver's passage through Clerkenwell carefully, Schwarzbach is right to note that the effect of the passage is nonetheless "like entering a maze" that presages "a nightmare vision of a bestial city of death" (Schwarzbach 1979: 46-7). Furthermore, although Oliver enters this "dark London" at a very specific point, the turnpike at Islington, "the labyrinth of London, appears

\footnotetext{
${ }^{6}$ The essays by Wagner, Villa, Nesvet and Horton map the ways imageability might function in other spatial contexts.
} 
to exist in a state of complete separation from the rest of the world" (Schwarzbach 1979: 45, 48), and the district's criminality takes Oliver by surprise when he witnesses the Dodger and his gang picking pockets on Clerkenwell Green (figure 3). Even after Oliver has escaped Fagin's den for a still rural Pentonville, running an errand for Mr Brownlow, he is again "dragged into a labyrinth of dark narrow courts" in the "low neighbourhood" when "he accidently turned down a by-street which was not exactly in his way" (Dickens [1837-9] 2003: 120, 123). Oliver's loss of his way recalls Lynch's observation that the "very word 'lost' in our language means much more than simple geographical uncertainty; it carries overtones of utter disaster" (Lynch 1960: 4). In the context of the novel, Oliver's loss of his bearings not only allows him to be recaptured by Fagin's gang but also signifies a generic shift to scenes of Gothicised criminality (figure 4). By contrast, the characters of The Nether World, unlike Oliver on their "native soil" in Clerkenwell (Gissing [1889] 1992: 322), are able to find their way through the district's confusing pathways. Daughter of an alcoholic mother and a violent father, Pennyloaf lives in the imaginary Shooter's Gardens slum:

To enter from the obscurer end, you descended a flight of steps, under a low archway, in a court itself not easily discovered. From without, only a glimpse of the Gardens was obtainable; the houses curved out of sight after the first few yards, and left surmise to busy itself with the characteristics of the hidden portion. A stranger bold enough to explore would have discovered that the Gardens had a blind offshoot, known simply as "The Court." ... filth, rottenness, evil odours, possessed these dens of superfluous mankind and made them gruesome to the peering imagination. The inhabitants of course felt nothing of the sort ... Pennyloaf ran into the jaws of this black horror with the indifference of habit; it had never occurred to her that the Gardens were fearful in the night's gloom, nor even that better lighting would have been a convenience.

(Gissing [1889] 1992: 74)

Possibly undiscoverable and certainly disorientating to an outsider, the slum fails to disconcert a local.

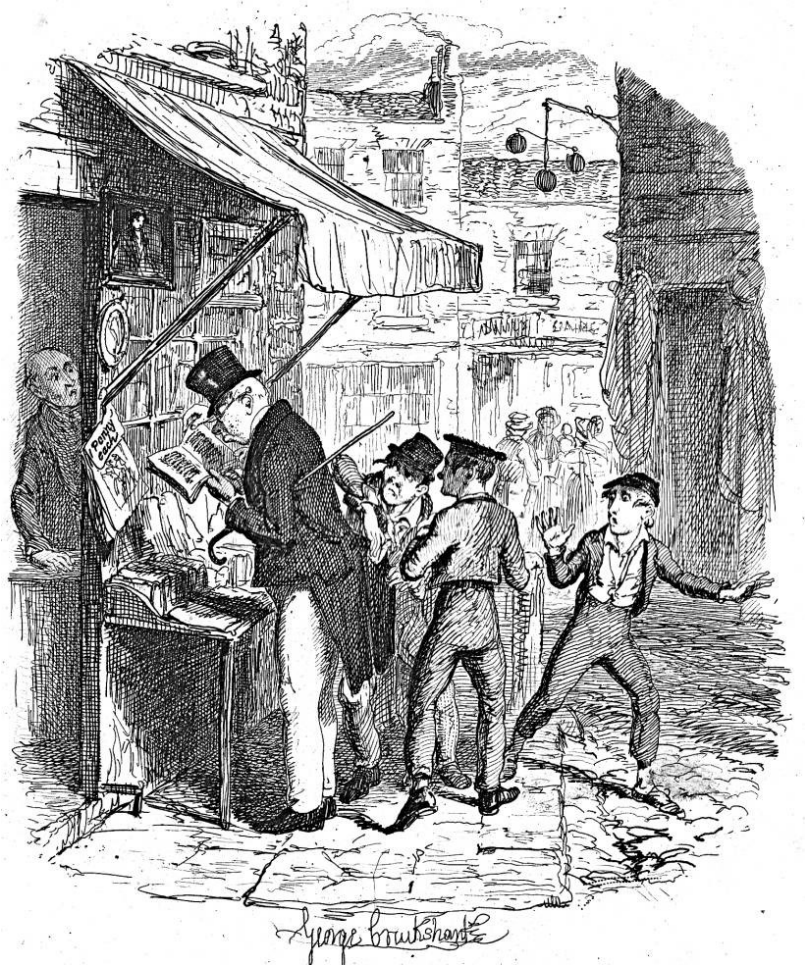

Figure 3. George Cruikshank. July 1837.

"Oliver amazed at the Dodger's mode of going to work."

Scanned by Philip V. Allingham. Victorian Web.

http://www.victorianweb.org/art/ illustration/cruikshank/ot6.html 


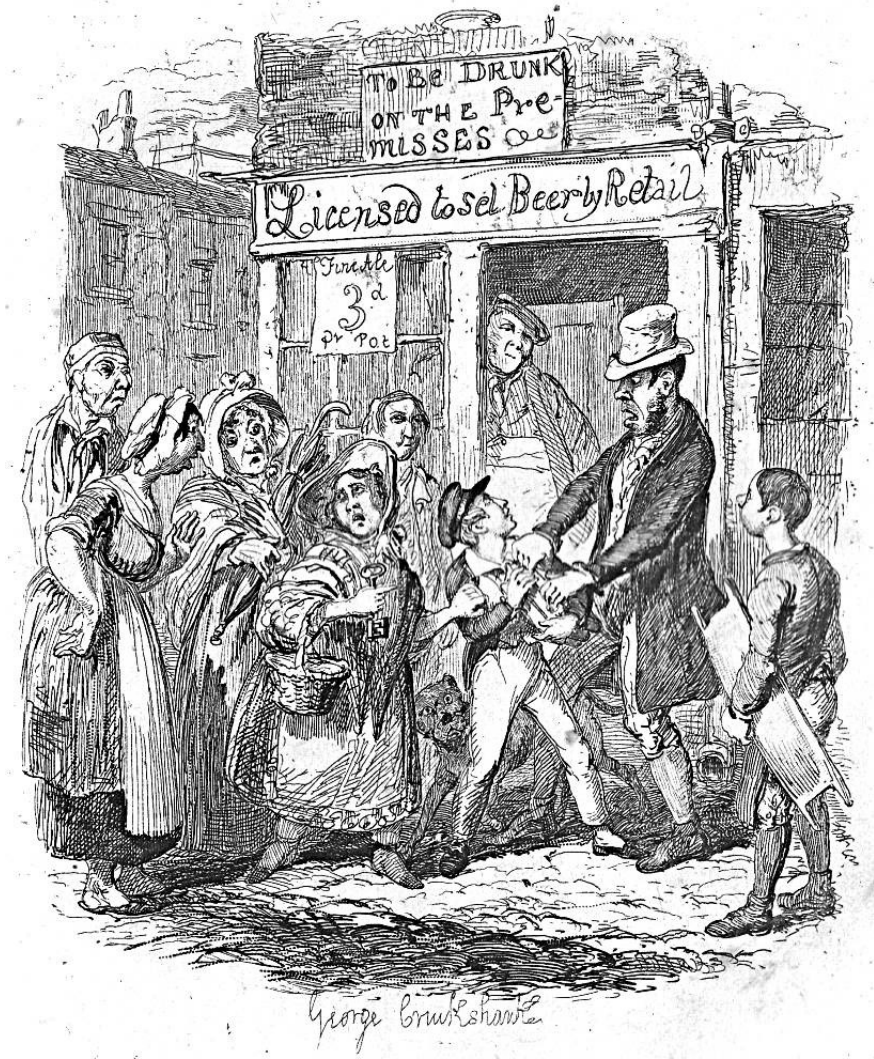

Figure 4: George Cruikshank. September 1837.

"Oliver claimed by his affectionate friends."

Scanned by George P. Landow.

Victorian Web.

http://www.victorianweb.org/art/ illustration/cruikshank/ot8.html

If Clerkenwell's paths were confusing, for most observers the district appears to have been defined by its strong negative landmarks: prisons, courthouses, the abattoir at Smithfield, and graveyards. This relentless association with inescapable incarceration recalls Michel Foucault's analysis of the "panoptic mechanism" characterising modern "disciplinary society" (Foucault [1975] 1991: 200, 209). Hemmed in on all sides by prison walls, courthouses and police stations, the inhabitants of Clerkenwell were seemingly under constant watch, as Bob Hewitt's reaction of "terror" to having "a hand chec[k] his progress" (Gissing [1889] 1992: 219) from behind testifies. Dickens's juvenile criminals live under the shadow of the gallows, and a powerful late scene contemplates the disordered thoughts of the novel's chief villain Fagin on his final, agonised night in Newgate. A "distant reading" of nineteenth-century digital newspaper archives supports this association of Clerkenwell with criminality. ${ }^{7}$ The visualisation tool of Gale Primary Sources reveals that the search term "Clerkenwell" stimulates a substantial number of hits that largely fall into semantic fields associated with the police and the courts; assault, violence and murder; social unrest, radicalism, arms and explosions; theft, burglary, robbery and coining; and cruelty to women, children and animals. ${ }^{8}$ Crucially, these negative "intertextual resonances," perpetuated in both fiction and the press, would have influenced both authors' and readers' perceptions of

\footnotetext{
${ }^{7}$ Sparks and Horton comment on distant reading and digital methodologies.

${ }^{8}$ Gale Primary Sources, mined on 22 December 2019, returns the following number of hits per decade for the search term "Clerkenwell": 1830-9: 1,602; 1840-9: 2,707; 1850-9: 4,035; 1860-9: 7,$737 ; 1870-9: 4,828 ; 1880-9: 4,863 ; 1890-9: 5,624$. The peak in the 1860 s was likely related to the "Clerkenwell Outrage," a Fenian attack on the prison in December 1867, with 1,745 hits in 1867-8.
} 
the area (Friday 2015: 234). This suggests that literary texts, not unlike physical landmarks within the actual cityscape, aid orientation and create imageability.

The Nether World, framed by graveyard scenes, operates against "a matrix of overbearingly panoptical coda" (Hutcheon 2018: 153), with Gissing's narrator, an exclamation mark indicating his surprise and aversion, describing local "children playing at midnight between slum and gaol!" (Gissing [1889] 1992: 32). This sense of incarceration and stunted growth is also gendered. Amy Levy deploys the "trope of a woman watching urban life from behind a windowpane ... to illustrate and protest limits to women's participation in urban life" (Evans 2010: 34). The view of Levy's Eleanor Lloyd "from her window in the roof" is limited to a "blank wall" and "a few sickly plane-trees," but by "craning her neck" she is able to glimpse the High Street and "envy the barmaid and the flower-girls their social opportunity" (Levy [1889] 2006: 227). Gissing's Clara Hewitt has, in fact, been that barmaid at the Imperial Restaurant and Luncheon Bar in the Angel, but has left her position for the life of a provincial actress, only to have to return to domestic incarceration in Clerkenwell after a vitriol attack by a jealous rival confines her to live behind closed doors. From her room in the Farringdon Road Buildings, she enjoys a panoramic view of London:

On a clear day the view from this room was of wide extent, embracing a great part of the City;
seen under a low, blurred, dripping sky, through the ragged patches of smoke from chimneys
innumerable, it had a gloomy impressiveness well in keeping with the mind of her who brooded
over it. Directly in front, rising mist-detached from the lower masses of building, stood in black
majesty the dome of St. Paul's; its vastness suffered no diminution from this high outlook,
rather was exaggerated by the flying scraps of mirky [sic] vapour which softened its outline and
at times gave it the appearance of floating on a vague troubled sea. Somewhat nearer, amid
many spires and steeples, lay the surly bulk of Newgate, the lines of its construction shown
plan-wise; its little windows multiplied for points of torment to the vision. Nearer again, the
markets of Smithfield, Bartholomew's Hospital, the tract of modern deformity, cleft by a gulf
of railway, which spreads between Clerkenwell Road and Charterhouse Street. Down in
Farringdon Street the carts, waggons, vans, cabs, omnibuses, crossed and intermingled in a
steaming splash-bath of mud; human beings, reduced to their due paltriness, seemed to toil in
exasperation along the strips of pavement, bound on errands, which were a mockery, driven
automaton-like by forces they neither understood nor could resist.

(Gissing [1889] 1992: 280)

This panoramic expanse, ironically, is no expression of Clara's power over the city that stretches before her, but rather mocks her "discontent and futile aspiration" in attempting to escape Clerkenwell in the first place (Gissing [1889] 1992: 281).

If Clara and Eleanor are unable to escape their confinement, the street-level knowledge of the district demonstrated by Dickens's Artful Dodger, Ainsworth's Jack Sheppard and Gissing's Bob Hewitt suggests an ability to evade the eye of disciplinary power. In Dickens's novel, it is Oliver who is caught on Clerkenwell Green as a pickpocket, whereas the Dodger and Charley Bates slip away. While Gissing's novel contains multiple instances of "stalwart policemen ... hustling forward" to clear disturbances, coiner Bob Hewitt is also able to recognise "police officers in plain clothes" "at a glance," giving him a chance to escape for a time (Gissing [1889] 1992: 112, 335). Jack Sheppard, meanwhile, is able to flee not only from Newgate - twice - but also from the New Prison in Clerkenwell, where, "load[ed] ... with fetters of unusual weight," he is confined with his paramour Edgeworth Bess "in a cell which, from its strength and security, was called the Newgate Ward" (Ainsworth [1839-40] 2010: 285). Yet Jack's “courageous spirit" and "wonderful industry" soon secure the pair's escape (figure 5), as Jack files through iron bars, bores through oak beams, eventually escaping the prison down a rope made out of Bess's clothing and then scaling "the wall of the 
Clerkenwell Bridewell, ... more than twenty feet high, and protected by formidable bristling chevaux-de-frise" (Ainsworth [1839-40] 2010: 287-8). Jack then makes use of his knowledge of the district, at the time still "open country ... abound[ing] in ... places of amusement," to effect his escape (Ainsworth [1839-40] 2010: 289-90). These locals with their ability to navigate Clerkenwell's confusing pathways recall Michel de Certeau's description of pedestrians as the "ordinary practitioners of the city" who "live ... below the thresholds at which visibility begins" (de Certeau [1984] 1988: 93). Sheppard's "very identity," Lauren Gillingham argues, "is premised on transgression of the social order, and on the unleashing of ambitious, appetitive energy" (Gillingham 2009: 886) that is essentially urban. ${ }^{9}$ However, as Simon Joyce observes, Newgate novels such as Jack Sheppard "often produce sites and moments of subversion only to neutralize them within larger narratives of containment and closure" (Joyce 2003: 60), and, like Bob Hewitt's, Jack's escape proves but temporary.

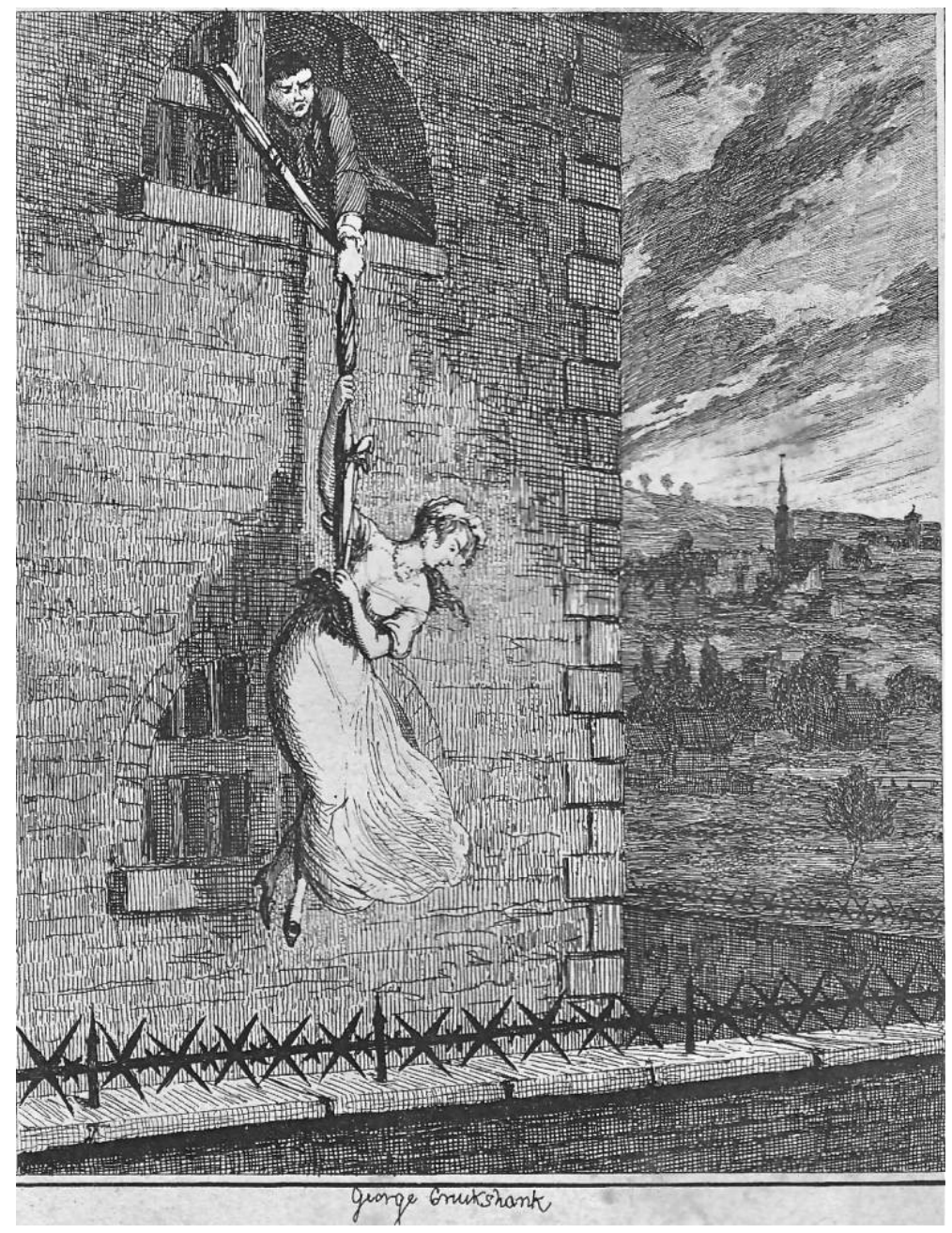

Figure 5. George Cruikshank. July 1839.

"Jack Sheppard and Edgeworth Bess escaping from Clerkenwell Prison." Scanned by Philip V. Allingham. Victorian Web.

http://www.victorianweb.org/art/illustration/cruikshank/js15.html

\footnotetext{
${ }^{9}$ Raine and Saunders identify similar trajectories of criminal knowledge of the city as central features of mid-century penny and crime fiction.
} 


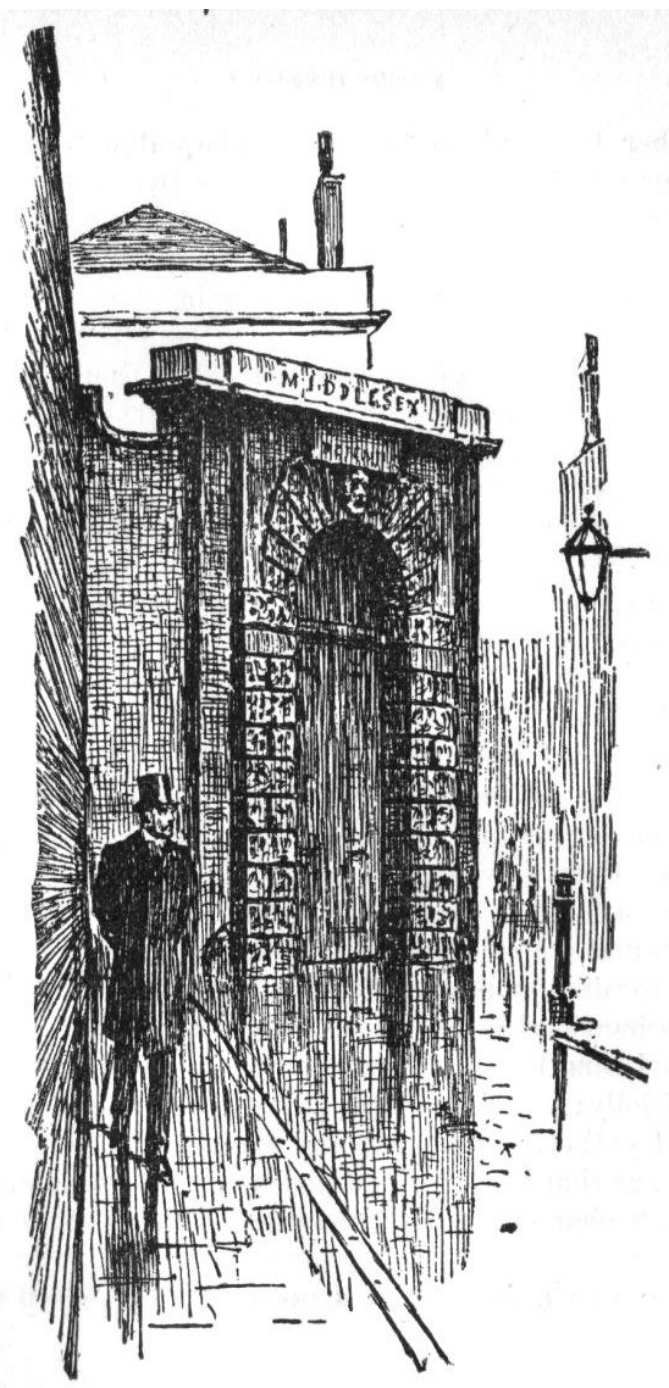

Figure 6. Untitled illustration by George du Maurier [1891] 1919.

Peter Ibbetson. New York and London: Harper: 147. Author's private collection.

In 1891, Richard Lovelace's subversive notion that "'Stone walls shall not a prison make, nor iron bars a cage!" (quoted in du Maurier [1891] 1919: 290) was fictionalised in perhaps the strangest of all Clerkenwell prison breaks. George du Maurier, famous for his cartoons in Punch and as the author of the sensationally successful Trilby (1894), began his authorial career in 1891 with the "moderately successful" Peter Ibbetson (Trammell 2018: 367), a novel that anticipates many of the occult themes and scenes of bohemian and French life that would make Trilby a success four years later. Initially serialised in Harper's New Monthly Magazine with 84 illustrations by the author, the novel was later successfully adapted for the stage, the screen, the opera, the radio and the musical (Leroy 2015: 2). Its eponymous bilingual Anglo-French protagonist is sent from a happy, artistic Parisian home filled with laughter, sunshine and flowers to the "cold fogs of Clerkenwell" (du Maurier [1891] 1919: 22) by well-meaning but misguided parents, who believe themselves to be acting in his interests. Ibbetson eventually ends up, appropriately enough, as an architect and surveyor in Wharton Street, Pentonville, the respectable northern part of Clerkenwell where Oliver's benefactor Mr Brownlow also resides, but which to Ibbetson "left much to be desired on the score of shape, color, romantic tradition, and local charm" (du Maurier [1891] 
1919: 105). Even the nearby slums of "Cow Cross - that whilom labyrinth of slaughterhouses, gin-shops, and thieves' dens, with the famous Fleet Ditch running underneath ... lacked the fascination and mystery" of "the slums of Paris," while their inhabitants "lacked the grace of French deformity, the ease and lightness of French depravity, the sympathetic distinction of French grotesqueness" (du Maurier [1891] 1919: 107-8). One ray of sunshine is provided by a fair tripe seller who "beautified and made poetical the hideous street that still bounds the Middlesex House of Detention on its western side" where her "large family ... sold tripe and pig's feet, and food for cats and dogs, in a very small shop" (du Maurier [1891] 1919: 146, 148). The accompanying illustration by du Maurier emphasises the bleakness of the street, the blankness of the prison wall and the imposing nature of the prison gateway topped by the effigy that marks the beginning of Gissing's novel (figure 6).

At a society gathering, Ibbetson meets the beautiful Mary, Duchess of Towers, and falls in love with her - hopelessly, he believes, until the two meet in a mutual "double dream" (du Maurier [1891] 1919: 245). Ibbetson's dream is initially one of "nightmare and oppression" and, perhaps inspired by his familiarity with Clerkenwell's negative landmarks of incarceration, the dream world dissolves into "a prison" with "a little thick-set jailer, three feet high and much deformed, and a little deformed jaileress," who attempt to "run [him] into the prison, where it was their custom to hang people on a Monday morning" (du Maurier [1891] 1919: 201). He is saved from this nightmare by the appearance in the dream of the Duchess, who "waved the troglodytes away" while the "prison tumbled down like a house of cards" (du Maurier [1891] 1919: 202-3). She then teaches him to "drea[m] true" so that he is able to visit the happy scenes of his childhood as they were years ago (du Maurier [1891] 1919: 201). This "great psychical discovery" of "the magic of dream-land" allows Ibbetson to escape his "dreary and commonplace" existence in London, "with such experiences to look back and forward to - such a strange inheritance of wonder and delight!" (du Maurier [1891] 1919: 218, 233). Ibbetson and Mary soon discover that they had been childhood friends and sweethearts in happier Parisian days, and begin to visit the past "dream space" together in their dreams (Trammell 2018: 365). When in a standard melodramatic plot twist Ibbetson accidentally kills his unpleasant and, it is implied, mixed-race uncle to protect his dead mother's honour, he accepts his life sentence, which the text implies he serves at the Middlesex House of Detention in Clerkenwell, "with a good grace and with a very light heart" (du Maurier [1891] 1919: 294). Leaving behind "sixteen hours' busy trance in the outer world" every evening, Ibbetson and Mary embark on nightly dream adventures "in the strange new world" where "[t]ime and space were annihilated" (du Maurier [1891] 1919: $308,363,335)$. His prison cell, Ibbetson concludes at the end of the novel, has been to him "a bower in the Elysian fields" (du Maurier [1891] 1919: 416), even when the "Dietary Table of Clerkenwell New Prison" discussed by the Resurrection Man and his associates in Reynolds's Mysteries of London equates prison diet with an attempt "to kill human beings by inches" (Reynolds 1846: n.p.). While the novel's framing structure leaves the reader in some doubt regarding Ibbetson's sanity - in another stock genre convention, his story reaches the public after his death in an asylum for criminal lunatics - the novel's interest in the science of dreams, potential unreliability of memory and theories of ancestral memory (Mann 2011) speaks powerfully to the fin-de-siècle fascination with the possibilities of occult communication and supernatural transport. ${ }^{10}$ In its provocative subversion of the prison walls for an embodied dream world, the novel also suggests that space can be psychological as much as physical.

\footnotetext{
${ }^{10}$ Bhattacharjee discusses the fin-de-siècle fascination with occult spatialities.
} 


\section{Mapping Journeys and Margins}

Peter Ibbetson's psychic travels are not the only journeys and dislocations in the Clerkenwell corpus. As Moretti notes, "the crossing of a spatial border" tends to "generate narrative" (Moretti [1998] 2011: 46, 37), while Brown contends that "borderlands ... can be the very place where cultural and political cross-currents, invisible on a map, meet" (Brown 2006: 19). While Clerkenwell fictions tend to be chiefly set within a small, seemingly self-contained area of London, they also acknowledge connections with the rest of London and indeed the world through narratives of travel. One notable example is Bob and Pennyloaf Hewitt's disastrous wedding-day excursion by train from Holborn Viaduct to Crystal Palace, which ends with an animalistic fight on Clerkenwell Green; another is Oliver's enforced journey via "Kensington, Hammersmith, Chiswick, Kew Bridge, Brentford" to commit burglary at Chertsey (Dickens [1837-9] 2003: 172). Other, longer journeys, by contrast, are largely implied rather than described in detail. Clara Hewitt's disappearance from the narrative when she leaves London for the life of a provincial actress is indicative of both her marginal social status as a fallen woman and of the provinces' lack of importance to the world of the novel; meanwhile, Michael Snowdon's return after years in Australia at the beginning of The Nether World and Joseph Snowdon's disappearance into North America at its end remind the reader of London's status as a "world city" (Schneer 2001: 10). ${ }^{11}$ The circularity of some of these journeys - Clara's failed attempt to leave, the graveyard scenes that open and close the novel - reinforce the sense of Clerkenwell's inescapability.

Perhaps more intriguingly, The Nether World also demonstrates tensions between a London of "strictly compartmentalised" districts and a "dynamic" city "open to progressive change" (Spiers 2006: 4) by situating certain characters and events transgressively on the margins of Clerkenwell (figure 7). Would-be-actress and fallen woman Clara Hewitt's attempt to improve her lot commences with a job as a barmaid in Upper Street, Islington (1), a post coveted by Levy's Eleanor Lloyd. Clara soon leaves her lodgings in "a dull street on the north of Pentonville Road" (2) for "a region of North London with which she had no acquaintance" (Gissing [1889] 1992: 92, 95). The fraudulent, pretentious, mutually destructive household of Joseph Snowdon and Clem Peckover is located in "rooms in Burton Crescent" (3), deemed "a [more] suitable quarter for a man of [Joseph's] standing" than Clem's native Clerkenwell Close, with Joseph's small "manufactory ... in a by-street on the north of Euston Road" (4) (Gissing [1889] 1992: 258, 199). Secretly wealthy Michael Snowden and his gentle granddaughter Jane, meanwhile, reside in Hanover Street (8), "to the north of City Road; it is a quiet byway, of curving form, and consists of dwellings only. Squalor is here kept at arm's length; compared with regions close at hand, this and the contiguous streets have something of a suburban aspect' (Gissing [1889] 1992: 64). Andrew Whitehead notes that while he never lived in Clerkenwell, Gissing had in fact in 1879-80 resided in Hanover Street with his wife Nell, whose death in 1888 prompted him to commence The Nether World (Whitehead 2010: 30). Intriguingly considering Clerkenwell's reputation, criminal activity and plotting are also placed on the margins of the district. Clem and Bob plot murder in "a shabby little place of refreshment, kept by an Italian," in "Old Street, not far from Shoreditch station" (5), and in the British Museum (6), while Bob's coining business operates in an "alley in the shadow of Bartholomew's Hospital" (7) (Gissing [1889] 1992: 260, 264). Meanwhile, Joseph Snowdon conspires with the shady lawyer

${ }^{11}$ Wagner, Villa, Nesvet and Horton discuss narratives of travel; Wagner emphasises the motifs of homecoming and inheritance that Gissing's novel deliberately subverts. 
Scawthorne, perhaps not illegally but certainly unethically, in Furnival Inn (9) and Lincoln's Inn (10).

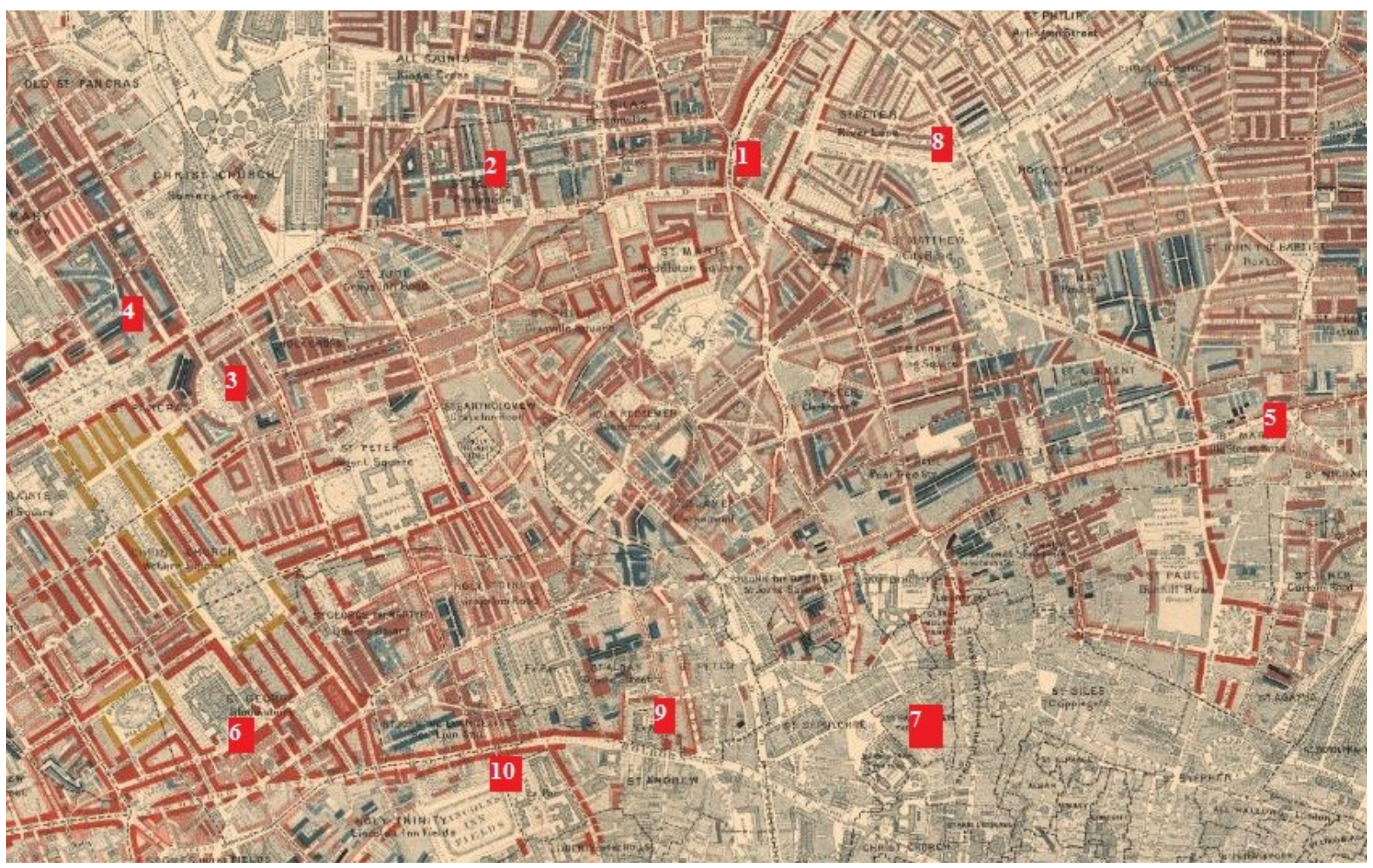

Figure 7. The margins of Clerkenwell in The Nether World:

1) Upper Street, Islington 2) North side of Pentonville Road 3) Burton Crescent 4) North side of Euston Road 5) Old Street 6) British Museum 7) St Bartholomew's 8) Hanover Street

9) Furnival Inn 10) Lincoln's Inn

Source: Author, created using Charles Booth's London: Poverty Maps and Police Notebooks. 2016. https://booth.lse.ac.uk. Licenced under Creative Commons Public Domain Mark 1.0.

Each of these settings on the outskirts of Clerkenwell, but always within walking distance of the Green, represents an attempt to improve one's social standing, not always legally or respectably. In the bleak philosophy of the novel, however, "journeys of progression are denied" (Hutcheon 2018: 95). Even the relocation of Sidney, Clara and the Hewitts at the end of the novel to a poorly built villa in Crouch End, far north of Clerkenwell and still "in the country a very short time ago," signals a defeat:

The streets have a smell of newness, of dampness; the bricks retain their complexion, the stucco has not rotted more than one expects in a year or two; poverty tries to hide itself with venetian blinds, until the time when an advanced guard of houses shall justify the existence of the slum.

(Gissing [1889] 1992: 364)

The depiction of Crouch End's recent suburban growth and likely decay reminds us of the novel's "rich sense of historical continuity," demonstrated among other instances by the narrator's "antiquarian delight" with St John's Arch, discussed above (Hutcheon 2018: 98). If, however, the nether world of Clerkenwell reveals itself to be "an archaeological site, a city built on layers of history, where, through depth, time can be conceived spatially and space, in turn, contains remnants of the past" (Hutcheon 2018: 98), Crouch End is but a "sham," lacking substance (Gissing [1889] 1992: 364). 
Indeed, time travel is one of the common journeys performed by the Clerkenwell corpus. As Peter Ackroyd observes, Clerkenwell's long-standing association with the manufacture of clocks and watches has led the district itself to appear "a vast mechanism emblematic of time and the divisions of time" (Ackroyd 2000: 472). The antiquarian reflections of Gissing's narrator are shared by Ainsworth's painstaking detailing of the "historical, geographical, and architectural specificity" of "Jack Sheppard's London" and the "differences between the cityscape of the early eighteenth century and his own London" (Baldwin 2013: 246-7). Du Maurier's Peter Ibbetson, meanwhile, journeys in his dreams far enough back in time to see a mammoth. Perhaps it is this "palimpsestic" quality (Ameel 2017: n.p.), evident in "the many continuities that charge Clerkenwell and its environs with an essential presence" (Ackroyd 2000: 461-2), that has led the area to "persis[t] in London's history as a kind of a shadowland" (Ackroyd 2000: 474) attractive to psychogeographers and cultural historians.

\section{Conclusions}

In an 1887 letter to Hardy, Gissing ponders "the question [of] how to get into a lifetime the work suggested by this myriad-voiced London" (Gissing 1992: 139). His question anticipates the challenges of geocriticism, a critical practice that stipulates engagement with "a number of different points of view, allowing diverse perspectives to flesh out, to round out, and perhaps to overcome the stereotyping or otherwise limiting images of a given place" (Tally 2011b: xi). "Geocriticism," Tally explains, "explores, seeks, surveys, digs into, reads, and writes a place; it looks at, listens to, touches, smells, and tastes spaces" (Tally 2011a: 2). Even limiting the enquiry to a particular time period and the "local detail" of a single district "rather than attempting to comprehend the city as a whole" (Sanders 2017: n.p.), the problem of the corpus is overwhelming. Indeed, Westphal, the foremost advocate of this critical approach, acknowledges that it "would be madness" "to undertake a full-scale geocritical analysis" of "places that are themselves artistically mythic" (Westphal [2007] 2011: 126-7).

However, this enquiry into representations and perceptions of nineteenth-century Clerkenwell has also demonstrated some of the advantages of a geocentric approach, particularly with reference to the interconnectedness of texts, genres and layers of history. "Derived from only a single source," Westphal writes, "the knowledge of a given space will be restricted, ... less valuable ... lopsided," while, "perceived and represented by more than one writer, it will be recentered (thus, geocentered)" (Westphal [2007] 2011: 126, 117). Such repositioning may help to mediate between contradictory perceptions, such as Gissing's bleak vision and Booth's contemporaneous but more optimistic view. At the same time, however, the intertextual and multi-layered analysis promoted by geocriticism reveals that literary maps exist in dialogue with each other: the frequency with which common themes and tropes recur suggests that spatial imagery is self-perpetuating, that generically specific literary worlds tend to generate other, aligned textual universes. The resulting literary landscape of Victorian popular fiction is, indeed, "a strange enough region wherein to wander and muse" (Gissing [1889] 1992: 11). 


\section{Bibliography}

Ackroyd, Peter. 2000. London: The Biography. London: Vintage.

Ainsworth, William Harrison. [1839-40] 2010. Jack Sheppard. London: Penguin.

Ameel, Lieven. 2017. "The City Novel: Measuring Referential, Spatial, Linguistic, and Temporal Distances." In The Routledge Handbook of Literature and Space, edited by Robert T. Tally Jr, n.p. [ebook]. London and New York: Routledge.

Bachelard, Gaston. [1958] 1994. The Poetics of Space, translated by Maria Jolas. Boston: Beacon Press.

Bakhtin, M. M. 1981. The Dialogic Imagination: Four Essays, edited by Michael Holquist, translated by Caryl Emerson and Michael Holquist. Austin and London: University of Texas Press.

Baldwin, Ruth. 2013. "Serial Criminal." Nineteenth-Century Contexts, 35.3: 237-52.

Baumgarten, Murray. 2008. "Fictions of the City." In The Cambridge Companion to Charles Dickens, edited by John O. Jordan, 106-19. Cambridge: Cambridge University Press.

Benjamin, Walter. [1927-40]. 2002. The Arcades Project, translated by Howard Eiland and Kevin McLaughlin. Cambridge, MA and London: Belknap Press of Harvard University Press.

Bennett, Arnold. [1923] 2016. Riceyman Steps. London: Penguin.

Brown, Peter. 2006. "Introduction." In Literature \& Place, 1800-2000, edited by Peter Brown and Michael Irwin, 12-23. Oxford, Bern, Berlin, et al.: Peter Lang.

Beckman, Linda Hunt. 2000. Amy Levy: Her Life and Letters. Athens: Ohio University Press.

Booth, Charles. [1902] 1969. Life and Labour of the People in London, 5 vols. New York: Augustus M. Kelley.

Buckley, Matthew. 2002. "Sensations of Celebrity: Jack Sheppard and the Mass Audience." Victorian Studies, 44.3: 423-63.

Charles Booth's London: Poverty Maps and Police Notebooks. 2016. https://booth.lse.ac.uk. Accessed 22 December 2019.

Collins, Philip. 1994. Dickens and Crime, 3rd edn. Houndmills: Macmillan.

Cook, Susan E. 2009. "Envisioning Reform in Gissing's The Nether World." English Literature in Transition, 1880-1920, 52.4: 458-75.

Coustillas, Pierre and Colin Partridge. 1972. Gissing: The Critical Heritage. London and Boston: Routledge \& Kegan Paul.

Cruikshank, George. 1839. "Jack Sheppard and Edgeworth Bess escaping from Clerkenwell Prison." Scanned by Philip V. Allingham. Victorian Web. http://www.victorianweb.org/art/illustration/cruikshank/js15.html. Accessed 22 December 2019.

Cruikshank, George. 1837. "Oliver amazed at the Dodger's mode of going to work." Scanned by Philip V. Allingham. Victorian Web.

http://www.victorianweb.org/art/illustration/cruikshank/ot6.html. Accessed 22 December 2019.

Cruikshank, George. 1837. "Oliver claimed by his affectionate friends." Scanned by George P. Landow. Victorian Web. http://www.victorianweb.org/art/illustration/cruikshank/ot8.html. Accessed 22 December 2019.

de Certeau, Michel. [1984] 1988. The Practice of Everyday Life, translated by Steven Rendall. Berkeley, Los Angeles, London: University of California Press.

Dennis, Amanda. 2017. "Heterotopias: The Possible and the Real in Foucault, Beckett, and Calvino." In The Routledge Handbook of Literature and Space, edited by Robert T. Tally Jr, n.p. [ebook]. London and New York: Routledge. 
Dennis, Richard. 2006. "Buildings, Residences, and Mansions: George Gissing's 'Prejudice against Flats." In Gissing and the City: Cultural Crisis and the Making of Books in Late Victorian England, edited by John Spiers, 41-62. Houndmills: Palgrave.

Dennis, Richard. 2004. “George Gissing (1857-1903): London's Restless Analyst.” Gissing Journal 40.3 (July): $1-15$.

Dennis, Richard. 2010. "Mapping Gissing's Workers in the Dawn." Gissing Journal, 46.4 (October): $1-20$.

Devine, Christine. 2001. "'Hell Constructed by Man': Depictions of the Poor in The Nether World." Gissing Journal, 37.1 (January): 1-17.

Dickens, Charles. [1860-1] 1999. Great Expectations, edited by Edgar Rosenberg. New York and London: W. W. Norton.

Dickens, Charles. [1837-9] 2003. Oliver Twist, or, The Parish Boy's Progress, edited by Philip Horne. London: Penguin.

Donnelly, Sue. 2002. "Mapping Rich and Poor: Putting Charles Booth's Enquiry into London Life and Labour Online." Cartographic Journal, 39.1: 81-5.

Duckworth, George H. 1898. Notebook: Police District 4 [Clerkenwell and Grays' Inn], District 5 [Old Street, Finsbury and Shoreditch], District 14 [West Hackney and South East Islington], District 15 [South West Islington]. BLPES MS BOOTH/B/353.

du Maurier, George. [1891] 1919. Peter Ibbetson. New York and London: Harper.

Englander, David and Rosemary O'Day. 1995. "Introduction." In Retrieved Riches: Social Investigation in Britain 1840-1914, edited by David Englander and Rosemary O'Day, 1-46. Aldershot: Scolar.

Englander, David and Rosemary O'Day. 1997. "Introduction." In The Streets of London: The Booth Notebooks - South East, edited by David Englander and Rosemary O'Day, 5-13. London: Deptford Forum.

Englander, David and Rosemary O'Day. 1993. Mr Charles Booth's Inquiry: Life and Labour of the People in London Reconsidered. London and Rio Grande: Hambledon.

Evans, Elizabeth F. 2010. “'We Are Photographers, Not Mountebanks!': Spectacle, Commercial Space, and the New Public Woman." In Amy Levy: Critical Essays, edited by Naomi Hetherington and Nadia Valman, 25-46. Athens: Ohio University Press.

Forster, John. 1872. The Life of Charles Dickens, vol 1. $9^{\text {th }}$ edn. London: Chapman and Hall.

Foucault, Michel. [1975] 1991. Discipline and Punish: The Birth of the Prison, translated by Alan Sheridan. Harmondsworth: Penguin.

Foucault, Michel. 1986. “Of Other Spaces,” translated Jay Miskowiec. Diacritics, 16.1 (Spring): 227.

Freud, Sigmund. [1919] 1990. "The 'Uncanny' (1919)." In The Penguin Freud Library, vol. 14: Art and Literature: Jensen's Gradiva, Leonardo da Vinci, and Other Works, translated by James Strachey, edited by Albert Jackson, 335-76. Harmondsworth: Penguin.

Friday, Linda. 2015. "Discovering Dracula's Coffins in the Digital Archive." Victorian Periodicals Review, 48.2: 232-7.

Fried, Albert and Richard M. Elman, eds. 1968. Charles Booth's London: A Portrait of the Poor at the Turn of the Century, Drawn from his "Life and Labour of the People in London." New York: Pantheon.

Frow, John. 2006. Genre. London and New York: Routledge.

Gale Primary Sources. Accessed 22 December 2019.

Gatrell, V. A. C. 1994. The Hanging Tree: Execution and the English people, 1770-1868. Oxford: Oxford University Press. 
Gill, Stephen. 1992. "Introduction." In The Nether World, by George Gissing, edited by Stephen Gill, vii-xxii. Oxford: Oxford University Press.

Gillingham, Lauren. 2009. "Ainsworth's Jack Sheppard and the Crimes of History." Studies in English Literature 1500-1900, 49.4: 879-906.

Gissing, George. 1992. The Collected Letters of George Gissing, vol. 3: 1886-1888, edited by Paul F. Mattheisen, Arthur C. Young and Pierre Coustillas. Athens: Ohio University Press.

Gissing, George. [1889] 1992. The Nether World, edited by Stephen Gill. Oxford: Oxford University Press.

Gissing, George. [1891] 1999. New Grub Street, edited by John Goode. Oxford: Oxford World's Classics.

Greenwood, James. 1869. The Seven Curses of London. London: Stanley Rivers.

Greenwood, James. 1874. The Wilds of London. London: Chatto and Windus.

Hardy, Thomas and Florence Hardy. [1928-30] 2007. The Life of Thomas Hardy, 1840-1928, edited by Michael Irwin. Ware: Wordsworth.

Harper, Charles G. 1904. The Hardy Country. London: Adam \& Charles Black.

Heidegger, Martin. 2011. Heidegger: Basic Writings from "Being and Time" (1927) to "The Task of Thinking” (1964), edited by David Farrell Krell. London and New York: Routledge.

Hertel, Kirsten. 2004. "In Darkest London: George Gissing's The Nether World as Urban Novel." Gissing Journal 40.1 (January): 12-35.

Hollingsworth, Keith. 1963. The Newgate Novel, 1830-1847: Bulwer, Ainsworth, Dickens, \& Thackeray. Detroit: Wayne State University Press.

Humpherys, Ann. 2011. "London.” In Charles Dickens in Context, edited by Sally Ledger and Holly Furneaux, 227-34. Cambridge: Cambridge University Press.

Hutcheon, Rebecca. 2018. Writing Place: Mimesis, Subjectivity and Imagination in the Works of George Gissing. New York and London: Routledge.

Irwin, Michael. 2006. "Maps of Fictional Space.” In Literature \& Place, 1800-2000, edited by Peter Brown and Michael Irwin, 25-48. Oxford, Bern, Berlin, et al.: Peter Lang.

Johnson, Samuel. [1755] 1994. Samuel Johnson's Dictionary of the English Language, edited by Alexander Chalmers. London: Studio Editions.

Joyce, Simon. 2003. Capital Offenses: Geographies of Class and Crime in Victorian London. Charlottesville and London: University of Virginia Press.

Keating, P. J. 1971. The Working Classes in Victorian Fiction. London: Routledge \& Kegan Paul.

Kimball, Miles A. 2006. "London through Rose-Colored Graphics: Visual Rhetoric and Information Graphic Design in Charles Booth's Maps of London Poverty." Journal of Technical Writing and Communication, 36.4: 353-81.

Lea, Hermann. [1906]. A Handbook to the Wessex Country of Thomas Hardy's Novels and Poems. London: Kegan Paul; Bournemouth: Holland Rowbottom.

Lefebvre, Henri. [1974] 1991. The Production of Space, translated by Donald Nicholson-Smith. Oxford: Blackwell.

Leroy, Maxime. 2015. "Distorted Dreams: Peter Ibbetson from Illustration to Adaptation." Cahiers victoriens et édouardiens, 82 (Automne): 2-17.

Levy, Amy. [1889] 2006. "Eldorado at Islington." In The Romance of a Shop, by Amy Levy, edited by Susan David Bernstein, 227-31. Peterborough, Ontario: Broadview.

Liggins, Emma. 2006. George Gissing, the Working Woman, and Urban Culture. Aldershot: Ashgate.

Ljungberg, Christina. 2017. "Reading as Mapping." In The Routledge Handbook of Literature and Space, edited by Robert T. Tally Jr, n.p. [ebook]. London and New York: Routledge. 
Long, William J. 1909. English Literature: Its History and Significance. Boston, MA: Ginn.

Lynch, Kevin. 1960. The Image of the City. Cambridge, MA and London: MIT Press.

Mann, Paisley. 2011. "Memory as 'Shifting Sand': The Subversive Power of Illustration in George Du Maurier's Peter Ibbetson.” Victorian Review, 37.1 (Spring): 160-80.

Mitchell, Peta. 2017. "Literary Geography and the Digital: The Emergence of Neogeography." In The Routledge Handbook of Literature and Space, edited by Robert T. Tally Jr, n.p. [ebook]. London and New York: Routledge.

Moore, Lewis D. 2008. The Fiction of George Gissing: A Critical Analysis. Jefferson, NC and London: McFarland.

Moretti, Franco. [1998] 2011. Atlas of the European Novel, 1800-1900. London and New York: Verso.

Moretti, Franco. 2013. Distant Reading. London and New York: Verso.

Moretti, Franco. [2005] 2007. Graphs, Maps, Trees: Abstract Models for Literary History. London and New York: Verso.

Orford, Scott, Danny Dorling, Richard Mitchell, Mary Shaw and George Davey Smith. 2002. "Life and Death of the People of London: A Historical GIS of Charles Booth's Enquiry." Health \& Place, 8: 25-35.

Osborne, Tomas and Nikolas Rose. 2004. "Spatial Phenomenotechnics: Making Space with Charles Booth and Patrick Geddes." Environment and Planning D: Society and Space, 22: 209-28.

Pfautz, Harold W., ed. 1967. Charles Booth on the City: Physical Pattern and Social Structure: Selected Writings. Chicago and London: University of Chicago Press.

Pinks, William J. [1863-5] 1881. The History of Clerkenwell, edited with additions by Edward J. Wood. $2^{\text {nd }}$ edn. London: Charles Herbert.

Poole, Adrian. 1975. Gissing in Context. London and Basingstoke: Macmillan.

Priestman, Martin. 1998. Crime Fiction from Poe to the Present. Plymouth: Northcote Council in association with the British Council.

Prieto, Eric. 2016. "Geocriticism Meets Ecocriticism: Bertrand Westphal and Environmental Thinking." In Ecocriticism and Geocriticism: Overlapping Territories in Environmental and Spatial Literary Studies, edited by Robert T. Tally Jr. and Christine M. Battista, 19-35. Houndmills and New York: Palgrave.

Pykett, Lyn. 2003. "The Newgate Novel and Sensation Fiction, 1830-1868." In The Cambridge Companion to Crime Fiction, edited by Martin Priestman, 19-39. Cambridge: Cambridge University Press.

Reeder, David. 1995. "Representations of Metropolis: Descriptions of the Social Environment in Life and Labour." In Retrieved Riches: Social Investigation in Britain 1840-1914, edited by David Englander and Rosemary O’Day, 322-38. Aldershot: Scolar.

Reynolds, George W. M. 1846. Mysteries of London, vol. 1. London: George Vickers. http://www.gutenberg.org/files/47312/47312-h/47312-h.htm\#page 002. Accessed 22 December 2019.

Said, Edward W. [1978] 1995. Orientalism: Western Conceptions of the Orient. Harmondsworth: Penguin.

Sanders, Julie. 2017. "Neighbourhoods: Thick Description in the City." In The Routledge Handbook of Literature and Space, edited by Robert T. Tally Jr, n.p. [ebook]. London and New York: Routledge.

Schilling, Derek. 2014. "On and Off the Map: Literary Narrative as Critique of Cartographic Reason." In Literary Cartographies: Spatiality, Representation, and Narrative, edited by Robert T. Tally Jr., 215-28. New York: Palgrave. 
Schneer, Jonathan. 2001. London 1900: The Imperial Metropolis. New Haven and London: Yale University Press.

Schwarzbach, F. S. 1979. Dickens and the City. London: The Athlone Press, University of London.

Schwarzbach, F. S. 2005. "Newgate Novel to Detective Fiction." In A Companion to the Victorian Novel, edited by Patrick Brantlinger and William B. Thesing, 227-43. Oxford: Blackwell.

Sharp, William. 1904. Literary Geography. London: Pall Mall Publications.

Simey, T. S. and M. B. Simey. 1960. Charles Booth: Social Scientist. Oxford: Oxford University Press.

Soja, Edward W. 1989. Postmodern Geographies: The Reassertion of Space in Critical Social Theory. London and New York: Verso.

Soja, Edward W. 1996. Thirdspace: Journeys to Los Angeles and Other Real-and-Imagined Places. Cambridge, MA and Oxford: Blackwell.

Spiers, John. 2006. "Introduction: Why Does Gissing Matter?" In Gissing and the City: Cultural Crisis and the Making of Books in Late Victorian England, edited by John Spiers, 1-29. Houndmills: Palgrave.

Stearns, Elizabeth. 2013. "A 'Darling of the Mob': The Antidisciplinarity of the Jack Sheppard Texts." Victorian Literature and Culture, 41: 435-61.

Tally, Robert T. Jr. 2014. "Introduction: Mapping Narratives." In Literary Cartographies: Spatiality, Representation, and Narrative, edited by Robert T. Tally Jr., 1-12. New York: Palgrave.

Tally, Robert T. Jr. 2011a. "Introduction: On Geocriticism." In Geocritical Explorations: Space, Place, and Mapping in Literary and Cultural Studies, edited by Robert T. Tally Jr., Foreword by Bertrand Westphal, 1-9. New York: Palgrave.

Tally, Robert T. Jr. 2017. "Introduction: The Reassertion of Space in Literary Studies." In The Routledge Handbook of Literature and Space, edited by Robert T. Tally Jr, n.p. [ebook]. London and New York: Routledge.

Tally, Robert T. Jr. 2013. Spatiality. London and New York: Routledge.

Tally, Robert T. Jr. 2019. Topophrenia: Place, Narrative and the Spatial Imagination. Bloomington: Indiana University Press.

Tally, Robert T. Jr. 2011b. "Translator's Preface: The Timely Emergence of Geocriticism." In Geocriticism: Real and Fictional Spaces, by Bertrand Westphal, translated by Robert T. Tally Jr., ix-xiii. New York: Palgrave Macmillan.

Temple, Philip, ed. 2008. Survey of London: Volume 46, South and East Clerkenwell. London: London County Council. British History Online. http://www.british-history.ac.uk/surveylondon/vol46/pp3-27. Accessed 22 December 2019.

Thacker, Andrew. 2017. "Critical Literary Geography.” In The Routledge Handbook of Literature and Space, edited by Robert T. Tally Jr, n.p. [ebook]. London and New York: Routledge.

Thacker, Andrew. 2003. Moving through Modernity: Space and Geography in Modernism. Manchester and New York: Manchester University Press.

Trammell, Matthew. 2018. “'Dreaming True': Embodied Memory, Transubjectivity, and Novelty in George du Maurier's Peter Ibbetson." Victorian Literature and Culture, 46: 365-79.

Villa, Luisa. 2006. "Gissing Saturnalia: Urban Crowds, Carnivalesque Subversion and the Crisis of Paternal Authority." In Gissing and the City: Cultural Crisis and the Making of Books in Late Victorian England, edited by John Spiers, 63-74. Houndmills: Palgrave.

Vuohelainen, Minna. 2015. Richard Marsh. Cardiff: University of Wales Press.

Walkowitz, Judith R. [1992] 2000. City of Dreadful Delight: Narratives of Sexual Danger in LateVictorian London. London: Virago. 
"Wanted in Clerkenwell." 1872. All the Year Round, (10 February): 250-3.

Westphal, Bertrand. [2007] 2011. Geocriticism: Real and Fictional Spaces, translated by Robert T. Tally Jr. New York: Palgrave Macmillan.

Whitehead, Andrew. 2010. "Clerkenwell as Hell - Gissing's 'Nether World'." Gissing Journal, 46.4 (October): 27-34.

Williams, Raymond. [1973] 1985. The Country and the City. London: Hogarth Press. 